\title{
EL DERECHO AL HONOR EN CUBA. FUNDAMENTOS PARA SU REFORMA
}

\author{
THE RIGHT TO HONOR IN CUBA. FOUNDATIONS \\ FOR ITS REFORM
}

\begin{abstract}
RESUMEN: El honor de las personas y la dignidad humana han sido enfocados históricamente por la ciencia jurídica como derecho fundamental, derecho subjetivo de la personalidad y bien jurídico a proteger, en dependencia de la rama del ordenamiento que lo regule. La polisemia del término ha generado enfoques distintos y en ocasiones contradictorios, produciendo antinomias como la que postula la irrenunciabilidad de los derechos subjetivos, en materia constitucional, a la vez que la normativa penal dispone la querella contra el ofensor, como forma del ejercicio de la acción para los delitos de esta naturaleza, lo cual suele ser interpretado como posibilidad de renuncia tácita a este derecho. La diversidad de enfoques en el tratamiento del derecho al honor en un ordenamiento no garantiza su sistemática, por lo que se requiere fundamentar una propuesta de reforma que se sustente en la unidad regulatoria, la sistematicidad regulatoria y la integridad funcional, como principios o ideas rectoras de su regulación jurídica.
\end{abstract}

Alie PÉREZ VÉLIZ*

Palabras claves: derecho al honor, bien jurídico, reforma, unidad regulatoria.

ABSTRACT: People's honor and human dignity have historically been considered by Legal Science as a fundamental right, subjective right of personality and legal property to be protected, depending on the branch of the legal system regulating it. The polysemy of the term has generated different approaches and sometimes contradictory, producing antinomies such as the postulation of the indispensability of subjective rights, constitutionally speaking, while criminal legislation provides for the complaint against the offender, like a form of exercise for the action of this nature, which is usually interpreted as tacit possibility of waiving this right. The diversity of approaches in the treatment of the right to honor within the system does not guarantee the systematic, so it requires supporting a proposal of reform that relies on regulatory unit, regulatory systematicity and functional integrity, as main principles or governing ideas of its legal regulation.

Descriptors: right to honor, legal property, reform, regulatory unit.

Licenciado en derecho y en historia; doctor en ciencias; profesor de Teoría del Estado y teoría del derecho; Historia del Estado y el derecho y de Filosofía del derecho de la Universidad de Pinar del Río "Hermanos Saíz Montes de Oca”, Cuba. 


\section{INTRODUCCIÓN}

El derecho al honor no ha sido plasmado como derecho fundamental en la Constitución de la República de Cuba, a pesar de que el Código Penal vigente sanciona los delitos contra el honor. Por su parte el Código Civil, Ley núm. 59 de 1987, en su artículo 38 establece que "La violación de los derechos inherentes a la personalidad consagrados en la Constitución, que afecte al patrimonio o al honor de su titular confiere a éste o a su causahabiente la facultad de exigir: a) El cese inmediato de la violación o la eliminación de sus efectos, de ser posible; b) La retractación por parte del ofensor; y c) La reparación de los daños y perjuicios causados". ${ }^{1}$

Esta forma poco plena e incoherente de regular el derecho al honor y la dignidad de las personas es resultado, en gran medida, del tratamiento que ha tenido dicho derecho en la doctrina y en la legislación. La polisemia del término ha generado enfoques distintos y en ocasiones contradictorios, lo cual produce antinomias como la que postula la irrenunciabilidad de los derechos subjetivos, en materia constitucional, a la vez que la normativa penal dispone la querella contra el ofensor, como forma del ejercicio de la acción para los delitos de esta naturaleza, lo cual suele ser interpretado como posibilidad de renuncia tácita a este derecho.

Resulta agravante, en el caso abordado, que el derecho al honor no tiene asidero constitucional, a pesar de un vago enunciado en favor de la dignidad humana, y esto sin carácter vinculante, en el preámbulo de la Constitución de la República. Tal falla hace impracticable, o al menos poco clara, una demanda por violación al honor de las personas, amparada en el artículo 38 de la normativa civil. Tampoco existe un proceso constitucional en Cuba, ni ha sido práctica de los tribunales cubanos acoger un asunto, o fundamentar una sentencia, con base en los derechos fundamentales de plasmación constitucional.

En el caso del ordenamiento jurídico estudiado, la diversidad de enfoques en el tratamiento del derecho al honor no garantiza su sistemática, por lo que se requiere fundamentar una propuesta de reforma que se sustente en la unidad regulatoria, la sistematicidad regulatoria y la integridad funcional, como principios o ideas rectoras de su regulación jurídica.

1 Ley número 59/87, Código Civil de la República de Cuba, La Habana, Editora del Ministerio de Justicia, 2003, p. 20. 


\section{EL DERECHO AL HONOR: BREVE ANÁLISIS DE DERECHO CONSTITUCIONAL COMPARADO}

No es hasta después de la Segunda Guerra Mundial que el derecho al honor adquiere una amplia plasmación constitucional. Un ejemplo típico es la Ley Fundamental de Bonn, de 23 de mayo de 1949, que postula en su artículo cinco, segundo acápite, luego de consagrar el derecho a la libertad de expresión "Estos derechos tienen sus límites en las disposiciones de las leyes generales, las disposiciones legales adoptadas para protección de la juventud, y el derecho al honor personal". ${ }^{2}$

La norma constitucional alemana refleja el derecho fundamental al honor como límite al ejercicio del derecho de expresión. Aunque se plasma de una forma indirecta, se recoge en la parte que corresponde del texto constitucional, la relativa a los derechos fundamentales; además se deja claro que el honor es un derecho, y se soluciona el posible conflicto entre éste y la libertad de expresión a favor del primero.

Otra Constitución que regula de forma explícita el derecho al honor es la española de 1978, que plasma en su artículo 18:

1. Se garantiza el derecho al honor, a la intimidad personal y familiar y a la propia imagen.

2. El domicilio es inviolable. Ninguna entrada o registro podrá hacerse en el sin consentimiento del titular o resolución judicial, salvo en caso de flagrante delito.

3. Se garantiza el secreto de las comunicaciones y, en especial, de las postales, telegráficas y telefónicas, salvo resolución judicial.

4. La Ley limitará el uso de la informática para garantizar el honor y la intimidad personal y familiar de los ciudadanos y el pleno ejercicio de sus derechos. ${ }^{3}$

De la letra del texto y de su forma de redacción se aprecia que el derecho al honor es concebido no sólo como un derecho fundamental, sino que complementa y se complementa con otros derechos de igual naturaleza. El grado de elaboración técnico-formal es alto, pues concibe límites al ejerci-

2 Prieto Valdés, Martha, Selección de textos constitucionales. Primera parte, La Habana, ENPSES, 1991, p. 91.

3 Ibidem, p. 233. 
cio de determinados derechos que, de abusarse de ellos, podrían traer una afectación al patrimonio moral de las personas.

En el ámbito latinoamericano, algunos textos constitucionales marcan la diferencia en cuanto a reconocer el derecho al honor de las personas de manera explícita. La Constitución de la República de Chile, a pesar de haber sido proclamada en 1980, en las condiciones excepcionales de ese país para la fecha, estipula en su artículo 19, acápite cuatro que la carta magna asegura a toda persona "El respeto y protección a la vida privada y pública y a la honra de la persona y de su familia". ${ }^{4}$

La Constitución Política de la República de Guatemala, de 31 de mayo de 1985, plasma en su artículo cuatro que "En Guatemala todos los seres humanos son libres e iguales en dignidad y derechos". ${ }^{5}$ Como puede apreciarse en este caso se utiliza el término dignidad, similar en su contenido al de honor, por lo que el autor considera que el constituyente está protegiendo el derecho al honor, definiendo con rango constitucional el reconocimiento y protección al bien jurídico patrimonio moral.

La Constitución de la Nación Argentina, de 22 de agosto de 1994, plasma en su artículo 43 el reconocimiento del derecho a ejercer acción contra cualquier forma de discriminación, siendo una vía indirecta de reconocimiento del derecho al honor. Es evidente que en este caso el constituyente plasmó un reconocimiento indirecto al patrimonio moral de las personas, al impedir cualquier forma de discriminación.

La Constitución Política de Colombia, de 7 de julio de 1991, plantea en su artículo 15 que "Todas las personas tienen derecho a su intimidad personal y familiar y a su buen nombre, y el Estado debe respetarlo y hacerlo respetar". ${ }^{6}$ Este es un caso que contiene de manera implícita el reconocimiento del derecho al honor, y por extensión la protección al patrimonio moral.

La Constitución de la República Bolivariana de Venezuela, de 20 de diciembre de 1999, reconoce y regula con gran amplitud el derecho al honor de las personas, aunque para ello emplea otros términos. En su artículo 46 estipula que "Toda persona tiene derecho a que se respete su integridad

4 Villabella Armengol, Carlos M., Selección de Constituciones iberoamericanas, La Habana, Félix Varela, 2002, p. 59.

5 Ibidem, p. 101.

6 Ibidem, p. 204. 
física, psíquica y moral"? Seguidamente el artículo relaciona con gran amplitud la forma en que esto se garantizará por el Estado, incluyendo la prohibición por parte de los funcionarios públicos de aplicar tratos crueles, inhumanos o degradantes; reconociendo el derecho de los detenidos al respeto de su dignidad, entre otros. La idea del respeto a la dignidad se reitera en otros artículos.

El análisis de la regulación del derecho al honor en las Constituciones, mediante el empleo del derecho comparado, permite establecer que existe una tendencia a reconocer de forma explícita el derecho al honor, pero para ello se utilizan diferentes términos y formas ambiguas de redacción, lo que no siempre permite visualizarlo como un derecho fundamental, propiciador de normas de desarrollo garantistas.

\section{EL DERECHO AL HONOR EN SU PERSPECTIVA HISTÓRICA}

Desde el establecimiento de los primeros códigos de la humanidad se formularon normas dirigidas a proteger el honor de las personas, considerando como tal a aquellos que no tenían la condición de esclavos, pues estos eran para el derecho objetos parlantes, y no sujetos de plenos derechos.

En el Código de Shulgi o de Ur-Nammu (aproximadamente entre 21002050 a. C.), joya del derecho mesopotámico antiguo, ya se regulaban sanciones pecuniarias para quienes atentaran contra el honor de una persona. En la Ley trece de dicho Código se establece: "Si un hombre acusa a (otro) hombre de brujería (y) al dios-Río lo ha llevado, (y si) el dios-Río lo declara inocente, el hombre que ha llevado (al otro al dios-Río) pesará tres GÍN de plata". 8

Obsérvese que aunque la norma no está estructurada en un sentido técnico formal moderno se puede apreciar en ella claramente una hipótesis, una disposición y una sanción. Se percibe en la redacción una mezcla de las materias penal y procesal, donde la hipótesis describe como elemento configurador la acusación de brujería por parte de un hombre contra otro.

7 Constitución de la República Bolivariana de Venezuela, Caracas, Talleres Gráficos de la Asamblea Nacional, 2005, p. 100.

8 Lara Peinado, Federico y Lara González, Federico, Los primeros códigos de la humanidad, Madrid, Tecnos, 2001, p. 65. 
En el supuesto se propone la prueba de la "ordalía fluvial", considerada una variante del juicio de Dios; la práctica de este medio de prueba ayudaría a establecer mediante la intervención de la voluntad divina la veracidad o no de la acusación. De ser falsa la acusación se sentenciará al culpable al pago de una multa. La disposición en este caso va dirigida a prohibir la falsa acusación, y aunque este es el delito que se configura, el bien jurídico protegido es el honor y la reputación de quien ha sido falsamente acusado.

La Ley catorce del propio Código regula que "Si un hombre acusa a una mujer casada de que ha tenido relaciones (sexuales) con ella (y si) el Río la ha declarado inocente, el hombre que (injustamente) la ha acusado pe[sará] un tercio [de mina de plata]". 9

El supuesto narrado en esta Ley es similar al anterior en cuanto a su estructura, pero debe señalarse que el honor que se protege aquí es el de la mujer casada, e indirectamente el de su esposo. La prueba de inocencia o culpabilidad que se práctica, es igualmente la de la ordalía fluvial, bastante extendida en ese momento.

La otra Ley del Código de Shulgi o de Ur-Nammu con enfoque a la defensa del honor es la quince, que compensa al futuro yerno en su dignidad, si el futuro suegro decidía casar a su hija con otro pretendiente. Dicha Ley obligaba al padre de la novia a devolver el doble de lo que había recibido en concepto de futuro matrimonio por parte del novio. Debe recordarse que este Código antecedió en trescientos años al de Hammurabi.

Otros documentos sumerios, que se elaboraban con el fin de familiarizar a los futuros escribas con el lenguaje jurídico, y que eran una especie de libros de textos de derecho, como es el caso de la serie Ana Ittishu, aparecían redactadas normas típicas que estipulaban cierta protección al honor de las doncellas. En este caso es válido señalar la serie siete y ocho del referido libro, que imitaba una norma que obligaba al hombre violador de una doncella a contraer con ésta nupcias, en satisfacción del honor de sus padres y de la propia joven.

Lo expuesto evidencia cómo desde el origen de la sociedad y del derecho ya se muestra una intención de proteger el honor de las personas, por lo menos de aquellas que eran consideradas como tal por su condición humana. Estas características se repiten en otras normas escritas y tradiciones de los Estados antiguos, tanto orientales como occidentales.

9 Ibidem, p. 65. 
En la Ley de las XII Tablas romana, que data del 451 antes de nuestra era, eran sancionados con severidad los delitos contra el honor. En la tabla VIII, de materia penal, que castigaba pocos delitos con la pena de muerte, los decenviros deciden aplicarla para quien "cantase o compusiera una canción que produjera la infamia o la deshonra de otro". ${ }^{10}$

En las reglas 3 y 4 de la propia tabla VIII se establecía la pena de multa de veinticinco ases contra el que injuriare a otro. Es interesante resaltar que en la regla 22 de la mencionada tabla se castigaba con la deshonra a quien fuera testigo o sostuviera la balanza en el rito emancipatorio y no otorgara el testimonio; se incluía como sanción accesoria para este caso la incapacitación para ser testigo y para castigar.

Los tres ejemplos señalados muestran la alta consideración que alcanza en el derecho romano el honor, siendo protegido como bien jurídico contra los delitos de infamia e injuria. La estimación del honor y del derecho a ostentarlo era tal que la deshonra, muy asociada a este, se consideró en sí misma una forma de sanción.

Más cercano en el tiempo, el derecho musulmán reguló la protección del honor de las personas mediante el castigo del delito de calumnia, el cual consistía en la falsa imputación de un delito de fornicación o adulterio. Obsérvese que en sus orígenes esta figura penal era similar a la actual calumnia, pero la sencillez de procedimientos para estos casos fue complejizándose con la evolución del derecho musulmán.

En la Edad Media el honor estuvo en el contenido de todos los códigos de caballería, creándose incluso las llamadas Órdenes de los Códigos de Caballería, después de las Cruzadas. En la Partida segunda, ley XII, título XXI, de las Siete Partidas de Alfonso el Sabio se estableció como formas de acceder a la hidalguía, y por tanto al honor y la consideración social, el saber expresado en el conocimiento y la práctica de las ciencias y artes liberales; y la bondad de las costumbres. Esta fue la forma en que se transfirió de las normas morales a las jurídicas el derecho al honor en el medioevo español.

Con la subida al poder de la burguesía, el honor se asoció a la consideración que ofrecía la propiedad y las riquezas, aunque no se limitaba a esto. La moral burguesa mantuvo incólume regulaciones tradicionales sobre el honor y la dignidad en el derecho de familia, obligando a la mujer a una

10 Ley de las XII Tablas, Madrid, Tecnos, p. 21 (otros autores, como Julio Fernández Bulté, ubican dichas regulaciones en la tabla VII, y en otras reglas). 
conducta debida ante la sociedad, la cual debía mostrar fidelidad y obediencia al esposo para conservar su honor.

Con el surgimiento de los Estados nacionales, y los modernos ordenamientos burgueses, la regulación del honor como derecho y deber se fue expandiendo a varias ramas o materias, entre las que se encuentran el moderno derecho constitucional; y adquirió nuevos contenidos en las reformulaciones del derecho penal, civil y de familia.

Después de la Segunda Guerra Mundial, con la firma de los tratados internacionales y la constitución de la Organización de las Naciones Unidas, se fueron incorporando a estos instrumentos del derecho internacional público la regulación del derecho al honor, a la dignidad humana y a la propia imagen. Un ejemplo de lo expresado se aprecia en el artículo 12 de la Declaración Universal de los Derechos Humanos, donde se expresa: "Nadie será objeto de injerencias arbitrarias en su vida privada, su familia, su domicilio o su correspondencia, ni de ataques a su honra o a su reputación. Toda persona tiene derecho a la protección de la ley contra tales injerencias o ataques". ${ }^{11}$

En instrumentos regionales como La Convención Americana sobre Derechos Humanos, o Pacto de San José de Costa Rica, se plasma un acuerdo similar, al estipular en su artículo 11 sobre protección de la honra y de la dignidad:

1. Toda persona tiene derecho al respeto de su honra y al reconocimiento de su dignidad.

2. Nadie puede ser objeto de injerencias arbitrarias o abusivas en su vida privada, en la de su familia, en su domicilio o su correspondencia, ni de ataques ilegales a su honra o reputación.

3. Toda persona tiene derecho a la protección de la ley contra esas injerencias o esos ataques. ${ }^{12}$

Luego de la explorar la regulación del derecho al honor en la historia de la humanidad se impone su análisis en Cuba. Para ello se emplearán los métodos del análisis histórico jurídico, el teórico doctrinal, y algunos elementos comparativos.

11 Declaración Universal de los Derechos Humanos, Instrumentos jurídicos internacionales, La Habana, Editorial Pueblo y Educación, 1991, t. I, p. 162.

12 La Convención Americana sobre Derechos Humanos (material en soporte digital). 


\section{EL DERECHO AL HONOR EN EL ORDENAMIENTO JURÍDICO CUBANO: ANTECEDENTES Y ESTADO ACTUAL}

Los antecedentes más remotos del derecho al honor en el ordenamiento jurídico cubano se remontan a los méritos que debían exhibir los primeros colonizadores para recibir a cambio derechos de posesión sobre tierras, minas e indios. El mérito, y por conducto de éste el honor personal, garantizaban la adquisición de riquezas, existiendo una fuerte interdependencia entre derecho al honor y derecho de propiedad, típico de una sociedad donde convivían la tradición feudal y los nuevos valores burgueses.

Para América en general y para Cuba en particular, el descubrimiento, la conquista y la colonización significaron una segunda oportunidad para los hijos desheredados y para los representantes de las clases desposeídas de la madre patria. Durante la Edad Media, el honor se recibía por herencia de sangre, mientras la conquista y colonización creó nuevas posibilidades para obtener victorias contra los indios y los europeos de potencias rivales, con lo que venía la fama, y con ella el engrandecimiento del honor personal, los títulos nobiliarios adquiridos y los derechos correspondientes.

En la real cédula del repartidor de indios de 8 de mayo de 1513, emitida por el rey de España, y que concedía a Diego Velázquez la facultad para repartir indios entre los conquistadores, se estipula la prelación en el reparto. Se favorece en orden sucesivo a los oficiales que hay en la isla, después a los primeros pobladores y descubridores españoles, posteriormente a los que tuvieren cédulas reales de reparto, y finalmente "á los que á vos mejor paresciere e bien visto fuere que merescen los dichos indios [sic]". ${ }^{13}$

Como puede apreciarse en esta norma, se deja a consideración del adelantado estimar los méritos personales para el reparto de indios, luego de listar aquellas categorías de personas que la Corona desea sean priorizadas. La vinculación entre mérito personal, honor y retribución económica, a lo largo del periodo, va a ser una característica que trasciende la etapa colonial en Cuba.

En las Ordenanzas de Alonso de Cáceres, que datan de 1573, se estipulaba exponer, mediante exhibición en la picota, el honor de las personas como forma de castigar los delitos menores. Este instrumento de administración

13 Pichardo Viñals, Hortensia, Documentos para la historia de Cuba, La Habana, Pueblo y Educación, 2000, t. I, p. 55. 
de justicia consistía en una columna erigida en lugares céntricos de las villas donde los sentenciados, tras ser azotados, eran expuestos a pública vergüenza.

La ordenanza número 40 de dicho instrumento jurídico sentenciaba: "Que el que pesare con peso ó medida falsa, por primera vez pague tres ducados, la tercera parte para el denunciador y juez, y las dos para el arca del consejo y se quiebre y ponga en la picota; y por la segunda sea esta pena doblada y esté en la cárcel diez días y por la tercera sea dado por falso [sic]". ${ }^{14}$

En la ordenanza 59 se habla de la calumnia, pero en el sentido de eximir de responsabilidad, y por ello de la aplicación de tal pena o castigo, al estanciero o mayoral que aprehenda a "cualquier negro cimarrón ó fugitivo", siempre que dé cuenta a las autoridades y a su verdadero amo.

Ambos ejemplos, que datan de los primeros cien años de la colonia, muestran cómo se estimaba el honor en la esfera del derecho: primero por vía del mérito para obtener fama y riquezas; y segundo como forma de castigo, para provocar la humillación y la vergüenza, mediante el azote y la exposición pública.

En el primer proyecto de Constitución para la Isla de Cuba (1812), de Joaquín Infante, se hace alusión en reiteradas ocasiones al honor o a alguno de sus atributos esenciales, aunque esto sea de forma indirecta. En este sentido se expresan los artículos 53 y 64; el primero, en lo relativo al procedimiento para enjuiciar a los funcionarios públicos de los principales ramos del Estado y del culto, que estipulaba para iniciar proceso la necesidad de "á lo menos quatro testigos contextes de buena reputación [sic]". ${ }^{15}$

En el mismo sentido se proyecta la redacción del mencionado artículo 64, cuando regula los requisitos a cumplir por los vecinos para formar parte del jurado para iniciar causas criminales. Entre los mencionados requisitos se encuentra tener "treinta años de edad, exentos de crímenes, y que sean de buena fama, y sana razon [sic]". ${ }^{16}$

En los dos artículos se aprecian formas de exteriorización del honor, verificadas en la buena reputación y la buena fama; son expresiones del honor y consideración del que goza una persona en el orden objetivo, en la esfera de las relaciones sociales. En este caso se trata del honor manifiesto, como

14 Ibidem, p. 55.

15 Matilla Correa, Andry (comp.), El Proyecto de Constitución para la Isla de Cuba de Joaquín Infante. Aproximaciones histórico-jurídicas a propósito de su bicentenario, La Habana, Facultad de Derecho de la Universidad de La Habana-Archivo Nacional de la República de Cuba, 2012, p. 85.

16 Ibidem, pp. 86 y 87. 
requisito o condición para formar testimonio o ser miembro de un órgano de enjuiciamiento criminal. Es otra variante de cómo se ha recepcionado en el tracto histórico del ordenamiento jurídico cubano el honor, pero no como derecho, sino como condición necesaria o requisito procesal.

Una interesante regulación establecida en la Constitución de Infante, y que hoy es debatida e incorporada a las llamadas leyes de medios en América Latina, es la relativa a la responsabilidad en el ejercicio de la libertad de expresión, particularmente por parte de la prensa, estipulándose que en su uso no se ofenda el dogma religioso y la moral, el sistema de gobierno, ni a los ciudadanos en particular. Esta Constitución protege, mediante una limitación al ejercicio del derecho de opinión, el derecho al honor, tanto de las personas como de las instituciones.

En el mismo proyecto de carta magna, en su artículo 98, se declaran "abolidas las penas crueles é ignominiosas, sin que dexe de imponerse la de infamia en las acciones aleves y rastreras, que subsistirá hasta rehabilitación á vuelta de una amelioración de conducta $[$ sic $]$ ". ${ }^{17}$

Este artículo estipula la prohibición de la aplicación de normas denigrantes para el honor de las personas, excepto aquéllas previstas para sancionar acciones alevosas y rastreras. Se aprecia en la norma cierta sobrevivencia de la Ley del Talión o del principio de justicia retributiva, imponiendo un castigo al sujeto comisor que se identificaba con el crimen cometido; era una forma de menguar el honor de quien ofendía el honor de otro.

En la tradición constitucional cubana, a partir de 1869, también se plasman de alguna manera normas relativas al honor de las personas. En un sentido restrictivo, para evitar excesos derivados de concesiones amparadas en el honor, y en el sentido de reforzar el principio de igualdad ante la Ley, el artículo 26 de la Constitución de Guáimaro estipulaba que "La República no reconoce dignidades, honores especiales, ni privilegio alguno". ${ }^{18}$

El derecho al honor es enfocado aquí desde la perspectiva del límite en su ejercicio; de determinar que no podía invocarse un honor especial recibido para ser acreedor de un tratamiento distinguido por parte de la Ley, que privilegiara a un ciudadano por este motivo y lo diferenciara de los demás. Esta es una exigencia para cualquier país que transite de ser colonia de una potencia monárquica a ser una república igualitaria, al menos en su expresión formal.

18 Pichardo Viñals, Hortensia, op. cit., p. 390. 
Fuera del ordenamiento jurídico mambí y del campo de derecho constitucional, el Código Penal español, extensivo a Cuba el 23 de mayo de 1879, introduce en la rama del derecho penal cubano los delitos contra el honor. Se trata de delitos contra el honor de los funcionarios públicos, protegiéndose a través de ellos la reputación y dignidad, no tanto del funcionario como persona particular, como de la dignidad o función pública que éste representa. En este caso, la especialidad del sujeto no está en quien cometió el delito, sino en el sujeto pasivo del mismo.

Aquí el bien jurídico que se protege es el desempeño adecuado de funciones públicas, en el ámbito de la administración y la jurisdicción. Esto se aprecia de la redacción del artículo 262, la cual estipula que cometen desacato: "Los que, hallándose un Secretario del Despacho ó una Autoridad en el ejercicio de sus funciones, ó con ocasión de éstas, los calumniaren, injuriaren ó insultaren de hecho ó de palabra en su presencia ó en escrito que les dirigieren, ó los amenazare". ${ }^{19}$

Es criterio de Ángel C. Betancourt, respecto del comentario al referido Código Penal, que el desacato en este artículo es una forma específica de los delitos de calumnia, injuria o amenazas, constituidos para él en razón de la persona ofendida. Luego de la emisión por el gobernador militar de la orden 213 de 1900, en que se despojaba la injuria de ser perseguida de oficio, para convertirse en cuasi pública, se sucedieron dos sentencias del Tribunal Supremo aparentemente contradictorias.

La primera de dichas sentencias data del 28 de marzo de 1904. En la misma el máximo órgano jurisdiccional declaró que con la orden militar 213 había dejado de existir el hecho punible de la injuria contra la autoridad, que era una de las conductas que constituía el delito de desacato. La otra sentencia, de 6 de marzo de 1919, por el contrario, no encuentra abolida la injuria contra funcionario público como delito, sino que la ve regulada en el artículo 48 de la orden militar 213.

Los artículos del 263 al 266, del referido Código, regulan unos supuestos que muestran un agravamiento de la pena por manifestación de figuras delictivas derivadas de la forma básica. Se aprecia que lo ocurrido fue que se sacó de la regulación del desacato la figura que califica como injuria, y ésta se trasladó, luego de ser reformada la norma penal, al artículo 486, en las disposiciones generales, quedando así:

19 Betancourt, Ángel C., Código penal, La Habana, Imprenta y Papelería de Rambla, Bouza y Co., 1922, p. 176. 
Nadie será penado por calumnia ó injuria, sino á virtud de querella de la parte ofendida, cuando la ofensa se dirija contra particulares, ó por denuncia de la misma si se dirige contra la Autoridad pública, corporaciones ó clases determinadas del Estado [...] En el primer caso el perdón de la parte ofendida extinguirá la acción penal ó pena si ya se hubiere impuesto al culpable. ${ }^{20}$

Pero es en el título X "De los delitos contra el honor” del referido Código Penal español, donde por primera vez y en forma sistémica se le da protección jurídica al honor y al patrimonio moral de las personas como bien jurídico. En dieciséis artículos se establecen los elementos constitutivos de los delitos de calumnia e injuria, así como las disposiciones y sanciones aplicables a cada caso.

La calumnia es definida en el artículo 471 como la falsa imputación de un delito de los que dan lugar a procedimientos de oficio. El delito de calumnia tiende a deshonrar y desacreditar al ofendido, al igual que la injuria, pero la imputación no se origina sólo en la frase empleada, ni de la intención con que ésta sea proferida o escrita, sino del hecho que concretamente se impute al ofendido, siempre que aquél sea falso y la imputación sólo tenga por objeto el desacreditarlo o deshonrarlo, o tienda a ese fin.

Como afirma Ángel C. Betancourt, "para que exista calumnia no es bastante que se emplee una denominación genérica y vaga del delito imputado, sino que es preciso que se concrete y especifique cuál es el hecho constitutivo del delito que se atribuye al calumniado [...] y que este hecho constituya un delito perseguible de oficio [...] y no cualquier delito". ${ }^{21}$

Hay una particularidad en cuanto a la calumnia, cundo la imputación que se hace por el presunto calumniador consiste en acusación ante funcionario obligado por los deberes de su cargo a perseguir dicho delito. En este caso, en realidad no se configura o tipifica un delito de calumnia, sino de falsa acusación, lo cual quedó refrendado por vía jurisprudencial en los fallos de 3 de junio de 1901 y de 13 de julio de 1903 del Tribunal Supremo de la República de Cuba.

El artículo 472 del Código ut supra mencionado regula los rangos penales aplicables en los supuestos de propagación por escrito y con publicidad, estableciendo en este caso prisión correccional en grado mínimo y medio, y

21 Ibidem, p. 260. 
multas de 250 a 2500 pesos cuando se imputare un delito grave; y de arresto mayor y multa de 125 a 1250 pesos, si se imputare un delito menos grave.

El artículo 473 concibe una atenuación de la pena cuando no exista propagación por escrito y con publicidad de la calumnia. En este caso se estipula un rango que oscila entre arresto mayor en su grado máximo y multa de 125 a 1250 pesos, en caso de imputación de un delito grave. Si el delito imputado es menos grave el rango penal oscila entre arresto mayor en su grado mínimo y multa de 65 a 650 pesos. La unidad de medida de los pagos previstos en estas sanciones es la actualizada luego de las reformas hechas al inicio de la República.

La gradación de las sanciones, teniendo en cuenta la propagación y publicidad de la calumnia, y la gravedad del delito imputado, demuestra la intención del legislador de adecuar la pena al grado de afectación en el honor del calumniado. Es una manera relativamente adecuada de protección del derecho al honor, en el sentido de que prevé una aplicación ponderada del principio de proporcionalidad entre el daño causado y la pena infligida.

El artículo 474 estipula una exención de pena para el acusado de calumnia en caso de que el hecho imputado se demostrare como cierto. La norma concibe una variante de satisfacción moral para quién sea víctima de calumnia, esta consiste en la publicación de la sentencia del tribunal actuante en caso de que el calumniado así lo pidiere. Es claro que corresponde en primer lugar al ofendido estimar la forma de reparación más adecuada a su honor, y por conducto de éste a su patrimonio moral.

El capítulo II, del título X, del Código Penal que estuvo vigente en Cuba de 1879 a 1938, regula el delito de injurias; como otra figura protectora del derecho al honor en la rama del derecho penal. Los elementos constitutivos del delito se conforman por "toda expresión proferida o acción ejecutada en deshonra, descrédito o menosprecio de otra persona". ${ }^{22}$

La propia norma enuncia taxativamente como injurias graves la imputación de un delito de los que no dan lugar a procedimiento de oficio; la de un vicio o falta de moralidad, cuyas consecuencias puedan perjudicar considerablemente la fama, crédito o interés del agraviado; las injurias que por su naturaleza, ocasión o circunstancias fueren tenidas en el concepto público por afrentosas; las que racionalmente merezcan la calificación de graves, atendiendo el estado, dignidad y circunstancias del ofendido y del ofensor.

22 Ibidem, p. 261. 
El artículo 477 establece la gradación de la pena para las injurias graves hechas por escrito y con publicidad, las cuales serán castigadas con la pena de destierro en sus grados medio y máximo, y multas de 625 a 6250 pesetas. El 478 establece una atenuación de la sanción para los casos de injurias leves, en cuyo supuesto la pena suministrada puede ser arresto mayor en su grado mínimo y multa de 325 a 3250 pesetas.

Al igual que en el supuesto de calumnia, se establece, para estos artículos, una aplicación ponderada del principio de proporcionalidad entre el daño causado y la pena infligida. Se percibe que la protección del bien jurídico: patrimonio moral, y como parte especial de él: el derecho al honor, se configuran a partir de delitos específicos con características diferenciadoras, pero que a la vez comparten semejanzas, tanto en sus elementos constitutivos, como en la forma en que se grada la pena atendiendo el grado de afectación provocado.

La norma realiza una interesante distinción en su artículo 479, al no admitir en el caso de la injuria las pruebas que confirmen la veracidad de la imputación; pero, con vista a la protección del ejercicio honorable de los cargos públicos, hace la excepción de admitir prueba de veracidad en caso de una imputación contra un empleado público, siempre que ésta sea sobre hechos concernientes al ejercicio de su cargo. En este caso, el acusado será absuelto si probare las imputaciones realizadas.

Esta norma refiere una especie de límite al ejercicio del derecho al honor, consistente en la protección al honor del cargo o ejercicio de funciones públicas. Se estaría, para algunos autores, en un supuesto de conflicto entre interés público e interés privado, en cuyo caso el legislador se pronunció a favor del interés público.

El capítulo tercero del Código plasma unas disposiciones generales que amplían los medios y formas de comisión, tanto del delito de calumnia como de la injuria. El artículo 480 incluye entre los medios de comisión de ambos delitos las alegorías, caricaturas, emblemas o alusiones. El penalista español Luis Jiménez de Asúa califica la comisión de los mismos por dichos medios como "calumnia e injuria encubiertas". ${ }^{23}$

El artículo 481 especifica cuándo se considerarán realizadas por escrito y con publicidad la calumnia y la injuria: cuando se propagaren por medio de papeles impresos, litografiados o grabados, por carteles o pasquines fi-

23 Jiménez de Asúa, Luis, Derecho penal, Madrid, Reus, 1924, p. 371. 
jados en los sitios públicos, o por papeles manuscritos comunicados a más de diez personas.

Es interesante significar que en el artículo 483 se establece una especie de antecedente de ley de medios, que impone determinada regulación de carácter obligatorio para los directores o editores de los periódicos en que se hubiera propagado la calumnia o injurias. En este caso, dichos directivos son personalmente responsables de insertar, dentro del término que establezca la Ley o decida el Tribunal actuante, la satisfacción o sentencia condenatoria, si lo reclamare el ofendido.

En el artículo 484 se establece la legitimación activa de ascendientes, descendientes, cónyuge y hermanos del difunto agraviado, siempre que la calumnia o las injurias trascendieren a ellos. También se establece que los herederos están legitimados para ejercer la acción penal. La Ley también permite el ejercicio de la acción cuando la calumnia o las injurias se hayan hecho en una nación extranjera.

$\mathrm{El}$ último artículo del título $\mathrm{X}$ determina algunos requisitos procedimentales especiales para que inicie y se extinga el proceso, incluyendo que en todo caso, cuando se trata de personas particulares, el mismo se haga mediante querella, y que se extinguirá la acción penal o la pena si mediare perdón del ofendido para el culpable.

En el caso de que la parte ofendida sea una autoridad pública, corporación u otra persona jurídica, el proceso iniciará por medio de denuncia ante el funcionario competente; en este supuesto se considerará público el delito, por lo que sólo procederá para extinguir la acción el indulto del Gobierno, o declaración, mediante auto, de extinción de la acción penal por la autoridad judicial.

Se aprecia un significativo paso de avance en el reconocimiento del derecho al honor, por la vía de su protección en sede penal. Hasta ese momento, en que dicho derecho no aparece de manera explícita recogido en ninguna norma constitucional, el derecho penal de indias tampoco lo había regulado, por lo que el Estado español en Cuba no había ejercido el ius puniendi contra quienes atacaban el bien jurídico "patrimonio moral" de las personas; quedando la solución de los conflictos de esta naturaleza en el plano privado, o bajo el arbitrio de autoridad administrativa, con los excesos que estas soluciones generalmente provocan.

No es hasta la Constitución de Leonardo Wood, de 20 de octubre de 1898, y puesta en vigor para regir en Santiago de Cuba y sus territorios aledaños, 
que se vuelve a hacer alusión al honor; en esta ocasión para estipular en su artículo segundo que nadie, por su creencia religiosa, podría ser privado de ocupar cargos de honor. El término se emplea de una forma ambigua, y este autor considera que se hizo con la intención de denotar el sentido honorable de los cargos públicos, más allá de la condición personal de la honorabilidad.

La Constitución de 21 de febrero de 1901 sólo se refiere en su artículo siete al honor, cuando relaciona las causas por las que se podía perder la ciudadanía cubana, siendo una de ellas recibir empleo u honores de otro gobierno. Aquí el término honor hace alusión al recibimiento de reconocimientos, títulos nobiliarios o condecoraciones; y la prohibición se limita a que dichos honores fueran autorizados por el Senado de Cuba.

Un salto cualitativo en la protección jurídico penal al honor de las personas lo constituyó el Código de Defensa Social, de 10 de febrero de 1936. En el título XII "Delitos contra el honor", en tres capítulos, donde se regulan la calumnia y la injuria, se hace nuevos aportes en cuando a adecuar la protección del bien jurídico "patrimonio moral" a las nuevas condiciones de desarrollo del derecho penal y de los medios de comunicación. Esto demuestra que durante mucho tiempo la protección del derecho al honor se desarrolló más en la rama penal que en otros campos del derecho.

El artículo 506, del Código de Defensa Social, define, similar al anterior Código Penal español, que la calumnia "es la falsa imputación de un delito de los que dan lugar a procedimiento de oficio". ${ }^{24}$

Los acápites B, C y D del mencionado artículo hacen una gradación de la pena teniendo en cuenta el nivel de afectación provocado al patrimonio moral del ofendido, y particularmente a su honor. El primero de los acápites establece que si es probada la publicidad de la calumnia será sancionado el culpable con penas que oscilan entre seis meses y un día y dos años, adicionándose a ello multas de cien a trescientas cuotas.

Se establece en el acápite $\mathrm{C}$ que si no se puede probar la publicidad, y por ello la afectación del derecho al honor es menor, el rango de la pena se rebaja de tres meses a un año, y multas de noventa a doscientas cuotas. El acápite $\mathrm{D}$ concibe una exención de responsabilidad del acusado si éste puede probar la veracidad de la imputación que ha realizado.

24 Martínez, José Agustín, Código de defensa social vigente en la República de Cuba, La Habana, Jesús Montero Editor, 1939, p. 390. 
El capítulo II del título XII regula el delito de injuria, definiéndolo como toda expresión proferida o acción ejecutada en deshonra, descrédito o menosprecio de otra persona. Para constatar la existencia de un delito de injuria, y por ello el ataque al honor de otra persona por esta vía, no debe tenerse en cuenta sólo el significado gramatical de las palabras o frases aisladas empleadas, sino también el sentido de las mismas dentro de la conversación o escrito que se suponga injurioso.

El acápite $\mathrm{B}$ del artículo 507 define como injurias graves la imputación de un delito de los que no dan lugar a procedimiento de oficio; la de un vicio o falta de moralidad que pueda perjudicar considerablemente la fama o crédito social o económico del agraviado; las expresiones o acciones que por su naturaleza, ocasión o circunstancias sean tenidas en el concepto público por afrentosas; las demás expresiones o acciones que racionalmente merezcan la calificación de injurias graves, atendiendo al estado, dignidad y circunstancias del ofendido y del ofensor.

Se utiliza la definición de injurias leves, mediante el método de exclusión, para todas las otras expresiones proferidas o ejecutadas en deshonra, descrédito o menosprecio de otra persona, y que no estén comprendidas en el listado de supuestos del acápite B del artículo 507.

Los artículos 508 y 509 establecen los marcos penales para las injurias graves y leves. Las injurias graves hechas con publicidad se sancionarán con privación de libertad de un mes y un día hasta seis meses, y con destierro de un mes y un día a seis meses; y con multas que oscilan entre treinta y una y ciento ochenta cuotas. El acápite B del propio artículo estipula una atenuación de la pena si las injurias graves se causaren sin publicidad.

En cuanto a las injurias leves, cuando se causaren con publicidad, el marco sancionador es puramente económico, con multas que van de treinta y uno a ciento ochenta cuotas. Las injurias leves causadas sin publicidad se sancionan en este Código con multas de cinco a sesenta cuotas.

El artículo 510 regula que al acusado de injurias no se le admitirá prueba alguna sobre la verdad o notoriedad de la misma, pero el mismo artículo establece como excepciones los casos en que la injuria se dirija contra un funcionario público, siempre que el hecho que se le atribuya se refiera al ejercicio de sus funciones; o si el injuriado demanda que el juicio se extienda a comprobar la verdad o falsedad del hecho que se le atribuya, entre otros supuestos. En estos supuestos excepcionales el acusado será absuelto si se comprueba la veracidad de las imputaciones. 
Donde hace un aporte el Código de Defensa Social con relación al anterior Código Penal español (extensivo a Cuba), es en lo relativo a definir los medios de propagación de la calumnia o la injuria, definiendo entre estos:

papeles impresos, litografías, grabados o por cualquier otro procedimiento mecánico de reproducción o difusión, por carteles o pasquines fijados en los lugares públicos, por papeles escritos dirigidos a varias personas, o si se comentan ante un concurso de personas por medio de discursos pronunciados o de gritos lanzados en reuniones públicas en circunstancias que faciliten su propagación, o por medio de la prensa o de la radio..$^{25}$

Obsérvese en este caso que se incluyen en la regulación nuevos medios de propagación de la información, que no existían al momento de aprobar el anterior Código Penal, como es el caso de la radio; a la vez que el legislador utiliza fórmulas con suficiente nivel de generalidad y predicción como para que pueda preverse la aparición de nuevos aparatos tecnológicos de difusión.

El legislador del Código de Defensa social además incluye conductas que podían existir con anterioridad, pero que en las condiciones de la colonia no se manifestaban, por las limitaciones que existían a las actividades políticas y sociales de la población: es el caso de los discursos en actividades públicas.

Otra novedad de Código de Defensa Social es que reconoce la posibilidad de la vulneración al honor de entidades y personas jurídicas, algo que no estipulaba el anterior Código. En este caso se acoge la idea, prevaleciente en la doctrina más avanzada del momento, de que las personas jurídicas tienen todos los atributos de la personalidad jurídica, incluido el derecho al honor. Correlativamente se incluye la posibilidad de que las personas jurídicas cometan delitos de calumnia e injuria, contra las cuales el artículo 512 supone la aplicación de una sanción de clausura temporal de dichas entidades, cuyo tiempo puede oscilar entre diez y sesenta días.

El nuevo Código amplía la responsabilidad de los medios de comunicación con la reparación del daño moral causado, y el menoscabo del honor al que tienen derecho todas las personas, ya sean naturales o jurídicas. En este sentido, si la calumnia o injuria se hubiera proferido en un periódico, los propietarios, gerentes o editores del mismo vendrán obligados a insertar, dentro del término que señale el Tribunal, y en el propio lugar y caracteres en que apareció la ofensa, la rectificación que el Tribunal ordenare.

25 Ibidem, p. 392. 
Se está garantizando con esto que el lector habitual del medio, que había leído la frase o frases calumniadoras o injuriosas, y que pudo haber bajado en su estima el honor y el patrimonio moral del calumniado, tenga la posibilidad de rectificar el criterio que falsamente se ha formado, constituyendo una especie de reparación moral del agraviado, así como una especie de tacha para la credibilidad del calumniador o injurioso.

$\mathrm{El}$ acápite $\mathrm{C}$ del artículo 513, en una ampliación de la responsabilidad de los medios de comunicación a sus directores o jefes de redacción, estipula:

En los delitos de injuria o calumnia cometidos por medio de la prensa o de la radio cuando no fueren conocidos los autores, o estuvieren éstos amparados por la inmunidad parlamentaria, derecho de extraterritorialidad o cualquier otro fuero, que impida su persecución, será estimado responsable el director del periódico o el jefe de redacción en su defecto, y el propietario y los operadores de la estación radiotransmisora. ${ }^{26}$

La norma muestra la intención del legislador de superar el abuso del derecho a la libertad de palabra y a la inmunidad. En este caso particular se configura como un dique de contención contra la vulneración del honor personal y el daño al patrimonio moral, estableciendo una corresponsabilidad de los directivos de los medios en los supuestos señalados por Ley.

En el propio artículo se prevé, en caso de inmunidad del director del medio, la posibilidad de que el Tribunal actuante disponga la clausura del periódico o la estación, por un periodo no menor de treinta días ni mayor de un año. Al decretar tal medida, el Tribunal tendrá en cuenta la periodicidad de la publicación, al efecto de computar como días de clausura los de la publicación únicamente.

Los artículos 514 y 515 establecen determinados requisitos que deben ser observados en los procesos por calumnias e injurias. Dentro de éstos se estipula la obligación del sancionado, a cualquiera de ambos delitos, de prestar caución de no reproducir la calumnia o la injuria objeto de la sentencia dictada por el tribunal.

Se estipula, al igual que en el anterior Código, que sólo procede iniciar proceso por cualquiera de los dos delitos si media una querella de la parte ofendida; que si muere durante el proceso la parte ofendida, o es víctima de estos delitos un fallecido, su cónyuge, ascendientes, descendientes, hermanos

26 Ibidem, p. 393. 
y herederos tienen legitimación activa para iniciar o continuar el proceso. A diferencia del Código Penal español, en el Código de Defensa Social, la legitimación de familiares y herederos no está limitada por la condición de que la calumnia o la injuria trasciendan al legitimado para actuar.

Otra novedad que tiene la norma es que se legitima para iniciar la querella a quien detenta la representación legal de la entidad ofendida, en el caso de las personas jurídicas perjudicadas en su honor. Esta regla complementa y sobre todo completa la cobertura y protección al patrimonio moral de las entidades, lo cual constituye un significativo avance.

Otras particularidades procesales de los delitos contra el honor, al amparo de este Código, tienen que ver con que en causa criminal no se autorizará el procedimiento de calumnia o injuria hasta tanto el Tribunal no haya dictado sentencia firme, o auto de sobreseimiento libre, también firme, o de sobreseimiento provisional o de abstención.

Similar al anterior Código, se acoge un proceso de calumnia o injuria, aunque las frases proferidas o escritas se divulguen o publiquen en el exterior. Sin embargo, éste tiene la particularidad de regular que para poder ser querellante tiene que tratarse de personas o entidades que residan en Cuba o que tenga aquí negocios. También se regula que la remisión de la sanción impuesta en los delitos de calumnia e injuria se configura en caso de perdón expreso del ofendido.

El Código de Defensa Social de 1936, bajo redacción y ponencia de José Agustín Martínez, consolidó en materia penal la defensa del derecho al honor, poniendo a Cuba entre las primeras naciones del momento. En esencia mantuvo la anterior regulación de los delitos contra el patrimonio moral de las personas, a través de la calumnia y la injuria, a la vez que introdujo importantes modificaciones, como considerar a las personas jurídicas como sujetos activos y pasivos de los referidos delitos. También amplió la descripción de los posibles medios de propagación y publicidad de la ofensa, a la vez que consolidó la protección contra la vulneración al honor de los medios masivos de comunicación.

En la esfera del derecho constitucional vuelven a aparecer regulados los aspectos relativos al honor en el artículo 20 de la Constitución de 1940, cuando se prohíbe de manera expresa toda discriminación por motivo de sexo, raza, color o clase, y cualquiera otra lesiva a la dignidad humana. Como se ha mencionado, el honor y la dignidad son conceptos íntimamente relacionados e interdependientes. 
Después de esta Constitución fue que comenzó a percibirse la necesidad de la regulación del derecho al honor con carácter sistémico, como una problemática del ordenamiento jurídico en general, y no como cuestión de una rama del derecho en particular. Sin embargo, la década del cincuenta del siglo XX en Cuba trajo un significativo retroceso en el reconocimiento y materialización del derecho al honor.

El golpe de Estado de 10 de marzo de 1952 y la sustitución de la Constitución de 1940 por los Estatutos Constitucionales no fueron el marco propicio para avanzar en materia de derechos humanos, mucho menos en el campo particular del derecho al honor.

El triunfo guerrillero del primero de enero de 1959 trajo muchas aspiraciones y realizaciones en materia de garantías. Transformaciones en las relaciones de propiedad, la educación, la cultura, el acceso de la población a los lugares públicos, y la lucha contra la pobreza, consolidaron el honor nacional y personal de los cubanos.

Pero la situación de provisionalidad institucional y jurídica, que se extendió desde el principio hasta la década del setenta, donde sobrevivieron normas anteriores con otras de carácter emergente, no creó en el ámbito jurídico formal ni teórico doctrinal un espacio de desarrollo y actualización del derecho al honor como derecho fundamental. En materia constitucional se mantuvo en esencia lo regulado en la Constitución de 1940, ahora como ley fundamental de 7 de febrero de 1959; mientras que en el derecho penal continuaron aplicándose las regulaciones del Código de Defensa Social, particularmente en lo relativo a los delitos contra el honor.

No debe olvidarse, sin embargo, que el empeño por construir una sociedad sustentada en valores morales diferentes, donde la fuerza de la influencia política tuvo un gran peso, los conceptos sobre la moral, el honor y la dignidad sufrieron modificaciones. Cambió el contenido de estos conceptos y la percepción social sobre cómo asumirlos, muchos de estos cambios fueron, a juicio de este autor, positivos, mientras otros no tanto.

En cuanto al reconocimiento del derecho al honor, la Constitución de la República de Cuba, de 24 de febrero de 1976, no lo recoge de manera explícita. Sin embargo, sería un error considerar que no está implícito en el articulado de la misma. El propio preámbulo reproduce una frase martiana, acogiendo el culto de los cubanos a la dignidad plena del hombre como ley primera de la nación. 
Por el lugar de su ubicación, en el preámbulo de la carta magna, y por su forma de redacción, la frase aludida es más una declaración política que una norma jurídica; si tiene gran vuelo ideológico no expresa una adecuada potencialidad de aplicación normativa. La materialización de la frase depende más de la voluntad política de las autoridades que de la implementación de mecanismos jurídicos constitucionales y administrativos exigibles.

La Constitución de la República, sin las reformas de 1992, recoge en los artículos 44, 64 y 123 de forma explícita algunos aspectos del derecho al honor. En el artículo 44 del mencionado texto se plasma que "El trabajo en la sociedad socialista es un derecho, un deber y un motivo de honor para cada ciudadano". ${ }^{27}$ Aquí lo concibe como efecto o atributo del derecho al trabajo, no como un derecho en sí mismo.

El artículo 64 plantea: "La defensa de la patria socialista es el más grande honor y el deber supremo de cada cubano". ${ }^{28}$ La formulación de este precepto es similar a la anterior, el honor es enfocado como derecho a defender la patria, en el mismo sentido que dicha defensa es un deber. El honor no se concibe aquí como un derecho en sí mismo, sino como forma de expresar otro derecho, que además tiene la categoría de deber, el de la defensa de la patria.

El artículo 123, al listar los objetivos de los tribunales, dejaba de forma explícita enunciado que uno de ellos era "amparar la vida, la libertad, la dignidad, el honor, el patrimonio, las relaciones familiares y demás derechos e intereses legítimos de los ciudadanos". ${ }^{29}$ Este era el artículo de la Constitución de la República que de forma más clara regulaba el derecho al honor, aunque fuera indirectamente, pues no se plasmaba en el capítulo referido a los derechos, deberes y garantías fundamentales.

Otra objeción que pudiera hacerse a la redacción del precepto enunciado es que no puede precisarse con claridad si la intención del legislador era declarar el honor como un derecho o como un interés. No obstante las deficiencias técnico formales que pudieran haberse señalado, el autor no cree oportuno que este artículo fuera suprimido de la Constitución de la República de Cuba en la reforma de 1992, sin haber plasmado de forma

27 Constitución de la República de Cuba, 24 de febrero de 1976, p. 12 (versión en formato digital).

28 Ibidem, p. 16.

29 Ibidem, p. 30. 
explícita el derecho al honor, en el capítulo correspondiente a los derechos, deberes y garantías fundamentales.

Con la supresión de la referida norma se deja sin amparo constitucional uno de los derechos que muchas Constituciones modernas contienen de manera explícita. Hay que reconocer que el artículo 123 fue transferido textualmente al artículo 4 de la Ley núm. 82 "De los tribunales populares", de 11 de julio de 1997; sin embargo, resulta cuestionable la regulación de derechos fundamentales en normas de inferior jerarquía cuando ese derecho no está preceptuado a nivel de la carta magna.

El análisis de la regulación del derecho al honor en las constituciones, mediante el empleo del derecho constitucional comparado, posibilitó establecer que a pesar de que en Cuba no se recoge de forma explícita, está reflejado en algunos de sus preceptos; mientras que en otros países se manifiesta una abundante y variada forma de constitucionalizar dicho derecho.

Si la plasmación del derecho al honor en el texto no garantiza su cumplimiento, por haber una diferencia entre Constitución formal y Constitución material, su omisión tampoco garantiza que se vaya a cumplir un precepto al que ni se ofrece el amparo legal para poder exigirlo, mediante los diversos mecanismos y procedimientos de control constitucional que confieren las leyes de los Estados.

Retomando el enunciado concepto de ordenamiento jurídico, el autor considera que en otras ramas del derecho la situación de regulación del derecho al honor en Cuba ha tenido resultados más felices. Un ejemplo positivo muestra el derecho penal, que ha seguido una trayectoria ascendente en la protección del patrimonio moral, desde su primera plasmación sistemática en el Código Penal español de 1879.

La Ley número 62 de 1987, Código Penal vigente, recoge en su título XII los delitos contra el honor. El antecedente inmediato de esta regulación es la Ley número 21 de 1979, la que ya incorporaba el delito de difamación como uno de los tipos penales configuradores de los delitos contra el patrimonio moral de las personas.

Lo que la Ley penal cubana recoge como delitos contra el honor, en muchos países latinoamericanos se incluye dentro de la regulación de los delitos contra las personas. Al regular en un título particular estos tipos de delitos, y teniendo en cuenta las características jurídicas especiales del bien 
protegido, el legislador cubano ha superado en su labor codificadora a los colegas de la región, a juicio de varios autores cubanos. ${ }^{30}$

Esto no quiere decir que la Ley penal sustantiva tenga una regulación perfecta desde el punto de vista teórico doctrinal y técnico formal, pues a ésta los mencionados autores le señalan que:

en el futuro la labor legislativa debería presidir la idea, en cumplimiento de los principios de legalidad, igualdad y certeza, de ajustar con mayor acierto jurídico estos tipos penales, en particular los de difamación y calumnia, atendiendo a que parte de su objetividad y finalidad jurídica la posee y da estructura a otros delitos como el desacato que prevé el artículo 144 y el de difamación de las instituciones y organizaciones de los héroes y mártires, regulado en el artículo 204 del Código Penal. ${ }^{31}$

Los referidos autores señalan que éstas no son las únicas deficiencias del Código arriba mencionado, y enuncian otras como la no incorporación de todos los delitos contra el honor en este título, y su dispersión en otros, como los casos de los artículos 113, 144 y 204. Además se cuestiona que al honor se le dé una doble connotación: como bien jurídico y como circunstancia modificativa de la responsabilidad penal (artículos 52-ch, 53-ñ y 320.2).

Como se ha dicho, los delitos contra el honor se regulan en el título XII de la Ley núm. 62 de 1987 (Código Penal vigente). La Ley retoma una figura delictiva de incorporación reciente a esta materia: la difamación, proveniente de la anterior Ley núm. 21 de 1979. Mientras se mantienen la calumnia y la injuria, llegadas a Cuba del Código Penal español, y actualizadas en el Código de Defensa Social, se profundiza, con la regulación del nuevo delito, en la protección del patrimonio moral de las personas.

La difamación se considera cometida, según refiere el artículo 318.1, cuando "El que, ante terceras personas, impute a otro una conducta, un hecho o una característica, contrarios al honor, que puedan dañar su reputación social, rebajarlo en la opinión pública o exponerlo a perder la confianza para el desempeño de su cargo, profesión o función social". ${ }^{32}$

30 Entre ellos se destacan Edmundo Larramendi Domínguez, Elia Esther Rega Ferrán, Mayda Goite Pierre, entre otros; en varios autores, Derecho penal especial, La Habana, Félix Varela, t. II, 2005.

31 Ibidem, p. 170.

32 Ley número 62/87, Código Penal, La Habana, Editora del Ministerio de Justicia, 2003, p. 134. 
La particularidad del delito de difamación es que con él se protege el honor objetivo, mientras la tradición en la legislación penal cubana protegía sólo el llamado honor subjetivo. Aquí se considera y valora la utilidad que tiene para la sociedad preservar la fe en las cualidades de quienes desempeñan un cargo, profesión o función social, por lo que el honor en este caso está asociado a esta actividad de gran significación social. Tanto el sujeto activo como el pasivo son sujetos generales, aunque por la redacción de la hipótesis de la norma parece que el pasivo se refiere a un sujeto especial.

La conducta antijurídica está conformada por la realización de imputaciones o acusaciones, designando en todo caso la persona contra la que va dirigida la imputación. La conducta imputada debe ser igualmente precisa, no basta con acusaciones vagas o genéricas. La revelación infamante tiene que ser hecha ante un tercero, sin que sea necesaria la presencia del ofendido. Este supuesto expresa una publicidad de las acusaciones vejaminosas, y por ello la exteriorización de la voluntad delictiva a través de la palabra o la escritura.

Para que se configure el delito de difamación es necesario que lo que se impute por el sujeto comisor sea una conducta, un hecho o una características. Esta conducta, hecho o característica puede haber acontecido en el pasado o en el presente, pero su revelación tiene que atacar directamente la estima y reputación de que goza el sujeto pasivo ante la sociedad; y como consecuencia debe "quedar expuesto a perder la confianza de la comunidad en virtud de la probidad exigida para su cargo, profesión o función social, todo lo que pudiera originar con entidad suficiente un reproche o repulsa del ente social en cuyo entorno se realiza el ataque al bien jurídico". ${ }^{33}$

Seguidamente se impone una sanción penal que oscila entre los tres meses y un año, o multas entre cien y trescientos pesos, o ambas. En este aspecto se aprecia la alta estimación que le confiere el Código al honor objetivo.

La doctrina, al valorar el elemento subjetivo de la difamación, acepta los diferentes grados de responsabilidad, que van desde el dolo genérico, pasando por la culpa hasta llegar a la imprudencia. Otro elemento asociado al anterior está enfocado a si existe o no la posibilidad de reparación del afectado, habiendo consenso entre los autores de que, por lo extraordinariamente sensible del bien atacado, ésta sólo puede ser moral, al amparo del artículo 70 del Código Penal vigente. 
Los apartados dos, tres y cuatro del artículo 318 ponen límites a la aplicación de la figura básica recogida en el apartado primero. En ellos, sucesivamente, se exonera de responsabilidad al inculpado si puede probar la certeza de las acusaciones; se rechaza la admisión de pruebas por parte del inculpado si este no tenía otro designio que denigrar a la víctima; y si el imputado no prueba la veracidad de sus acusaciones, o éstas son falsas, o se retracta, el tribunal lo consigna así en la sentencia, y debe dar a la víctima la debida constancia del hecho.

Algunos penalistas cubanos ${ }^{34}$ han alertado que la difamación puede entrar en concurso con los delitos previstos y sancionados en los artículos 144.1.2, de denuncia o acusación falsa, y con el 154.1, de difamación de las instituciones y organizaciones, y de los héroes y mártires. La propuesta de solución a este concurso es aplicar la variante de determinación de las particularidades del sujeto pasivo, en el primer caso, y de aplicación del principio de especialidad, en el segundo.

En cuanto a la regulación de los delitos de calumnia e injuria, la Ley número 62 de 1987 difiere sustancialmente de la definición que se ha dado en la tradición jurídica cubana, y en el actual Código Penal español. Mientras el Código patrio define la calumnia en su artículo 319 como divulgación a sabiendas de "hechos falsos que redunden en descrédito de una persona", ${ }^{35}$ la normativa penal española, en su artículo 205, lo conceptualiza como la "imputación de un delito hecha con conocimiento de su falsedad o de temerario desprecio hacia la verdad". ${ }^{36}$

Los autores cubanos antes mencionados reconocen que el Código Penal patrio se aparta de la doctrina mayoritaria en la formulación del delito de calumnia. En este delito el sujeto activo puede ser cualquier persona, y la acción antijurídica consiste en divulgar hechos falsos que redunden en la pérdida del crédito público de que goza una persona. En la Ley penal cubana se protege tanto el honor objetivo como el subjetivo.

Para la distinción de la ofensa al honor subjetivo y objetivo, los autores cubanos refieren:

34 Entre ellos se destacan Edmundo Larramendi Domínguez, Elia Esther Rega Ferrán, Mayda Goite Pierre, entre otros; idem.

35 Ley número 62/87, op. cit., p. 134.

36 Serrano Gómez, Alfonso y Serrano Maillo, Alfonso, Derecho penal. Parte especial, Madrid, Dykinson, 2006, p. 296. 
Esto implica que la acción ha de tener un significado objetivamente ofensivo, es decir, ha de considerarse socialmente que deshonra, desacredita o menosprecia a otra persona. Cuando la calumnia se vierte o profiere ante el propio ofendido, es el honor en sentido subjetivo, su autoestimación o el concepto de la propia valía el que se coloca en peligro; mientras que cuando la imputación se verifica a espaldas del destinatario de la misma, es el honor objetivo de éste el vilipendiado y agraviado, esto es, el concepto público que merece en el entorno social. ${ }^{37}$

Una condición básica y elemento constitutivo del delito de calumnia es que el hecho imputado ante tercera persona sea falso, ya sea porque el hecho no ocurrió, o porque la víctima no es la que lo realizó. Esta contradicción entre lo que pasó realmente, o lo que no pasó, y lo afirmado por el sujeto activo, es fundamental; por ello, de demostrarse que es cierta la imputación hecha por el presunto calumniador, la conducta pierde su tipicidad, por no serlo el hecho que le dio origen, constituyéndose un supuesto de inadmisibilidad de la querella.

En la valoración del elemento subjetivo del delito de calumnia es fundamental la voluntad del agente comisor de atacar la integridad moral, y con ella el honor de la víctima; las expresiones del artículo 319.1 "a sabiendas" y "divulgue hechos falsos", sugieren una actuación consciente y voluntaria de éste, tendente a desacreditar y hacer perder la reputación, el honor, que ostenta la víctima. En este caso se hace clara la mala fe del sujeto activo del delito.

En el artículo 319 se prevén dos rangos sancionadores, uno general, cuya pena oscila de seis meses a dos años de privación de libertad o multa de doscientas a quinientas cuotas. Mientras en el apartado segundo se concibe una atenuación de la pena para el culpable que reconoce la falsedad de sus imputaciones y se retracta de ellas ante el Tribunal; en este caso la pena oscila de tres meses a un año, o multa de cien a trescientas cuotas. Se estipula además que el Tribunal debe dar a la víctima la constancia de la retractación.

El Código Penal español concibe la calumnia, a diferencia del cubano, como una modalidad agravada de la injuria, pues los hechos que se tipifican como delitos responden a un especial rechazo por parte de la sociedad, lo que proviene de la peligrosidad social del hecho. 
En cuanto a la pena por calumnia, el rango sancionador que prevé el Código Penal español para su figura agravada (con publicidad) es similar al estipulado por el Código Penal cubano, sin la atenuación del 319.2: "prisión de seis meses a dos años o multa de 12 a 24 meses". ${ }^{38}$

No obstante debe reconocerse que en el caso de la Ley penal de Cuba, ni en la difamación ni en la calumnia se exige, como elemento constitutivo de la figura agravada, que los hechos divulgados sean constitutivos de delitos, como sí lo comprende la mencionada Ley española. El agravamiento de la pena en la normativa penal cubana va determinado básicamente por el conocimiento del agente comisor de la falsedad del hecho imputado, y no por la gravedad de la imputación, como parece ser la razón del agravamiento de la sanción penal en el Código español.

La injuria, como delito contra el honor, aparece regulada en el Código Penal cubano en el artículo 320.1, donde se estipula que "El que, de propósito, por escrito o de palabra, por medio de dibujos, gestos o actos, ofenda a otro en su honor, incurre en sanción de privación de libertad de tres meses a un año o multa de cien a trescientas cuotas". 39

El enfoque de los autores cubanos ${ }^{40}$ en cuanto a la injuria es que ésta es un delito de conducta genérica contra el honor, y que se diferencia de la difamación y de la calumnia de que lo atacado es el honor subjetivo, el concepto y estima que tiene la persona de sí mismo, y no el honor de que goza el sujeto ante la sociedad, en cuyo caso sería el honor objetivo.

En el caso del delito de injuria se requiere de tres elementos: "el primero objetivo, representado por las expresiones proferidas o acciones ejecutadas; el segundo, de marcado signo subjetivista, representado por el animus injuriandi, elemento subjetivo del tipo; y el tercero, relacionado con la valoración de la magnitud de la ofensa que sirve de mesura para los efectos punitivos". ${ }^{41}$

Como puede apreciarse en los tres casos señalados de delitos contra el honor, la protección del patrimonio moral de las personas en Cuba está parcialmente garantizada, a partir de que el Código Penal vigente lo establece, aunque en las disposiciones complementarias del título XII estipule que los

38 Serrano Gómez, Alfonso y Serrano Maillo, Alfonso, op. cit., p. 296.

39 Ley número 62/87, op. cit., p. 135.

40 Entre ellos se destacan Edmundo Larramendi Domínguez, Elia Esther Rega Ferrán, Mayda Goite Pierre, entre otros, en varios autores, op. cit.

41 Ibidem, pp. 187 y 191. 
delitos de calumnia e injuria sólo son perseguibles en virtud de querella, y que en la difamación se exija la denuncia de la parte ofendida; máxime cuando el derecho al honor no está reconocido como derecho fundamental, con identidad propia, en la Constitución de la República, y en el resto del ordenamiento jurídico no tiene la amplitud regulatoria que debería.

Asumiendo el análisis de la regulación del derecho al honor en el ordenamiento jurídico cubano, en otra rama del derecho que tiene presencia es en la civil. La Ley número 59 de 1987, Código Civil de la República de Cuba, regula en su libro primero, título segundo, sección cuarta, los llamados derechos inherentes a la personalidad. En este aspecto establece en su artículo 38 que:

La violación de los derechos inherentes a la personalidad consagrados en la Constitución, que afecte el patrimonio o el honor de su titular confiere a éste o a sus causahabientes la facultad de exigir:

a) el cese inmediato de la violación o la eliminación de sus efectos, de ser posible;

b) la retractación por parte del ofensor; y

c) La reparación de los daños y perjuicios causados. ${ }^{42}$

La Ley Civil sustantiva reconoce el derecho al honor, pero por vía indirecta, pues remite a los derechos inherentes a la personalidad consagrados en la Constitución, en cuyo articulado no aparece ninguno que consagre de forma expresa el derecho al honor; luego ella asume el honor como un atributo que puede ser afectado, junto al patrimonio, de cualquier titular de los derechos constitucionales.

Esta formulación no deja claro si el honor es reconocido como un derecho por el Código Civil o si es un simple atributo que debe ser afectado para conceder el derecho del titular a emplear la facultad de exigir cualquiera de los medios para el cese de violaciones de derecho y sus formas de reparación, previstos en los incisos a, b y c del propio artículo 38. Una forma de superar esa ambigüedad es plasmar de forma amplia, y a la vez precisa, el derecho al honor en la Constitución y en el resto del ordenamiento jurídico cubano.

Para sólo hacer una referencia al respecto, en el ordenamiento jurídico español se consagra el derecho al honor, con identidad propia, en el artícu-

42 Ley número 59/87, op. cit., p. 20. 
lo 18 de la Constitución, a la vez que se protege en el Código Penal en el libro II, título XI, mediante el castigo de los delitos de calumnia e injuria.

Por si esto fuera poco, y dándole un carácter verdaderamente sistémico a la institución, el Código Civil español acoge medios de protección para la reclamación en favor del honor, mientras que para fortalecer este derecho en sede Civil se aprobó el 5 de mayo de 1982 la Ley Orgánica 1/1982, de Protección Civil al Honor, la Intimidad Personal y Familiar y a la Propia Imagen.

Esto demuestra que pese a su realización material en favor del derecho al honor, el ordenamiento jurídico cubano presenta carencias en su reconocimiento, por lo que no goza de identidad propia, y de la amplitud y profundidad que requiere en dicho ordenamiento. El ejemplo de otras naciones, sin que implique una imitación mecánica, puede servir de inspiración para hacer las transformaciones técnico-jurídicas requeridas, a favor de un funcionamiento armónico de nuestro derecho y del sistema político de la sociedad.

\section{FUNDAMENTOS PARA LA REGULACIÓN DEL DERECHO AL HONOR EN CUBA}

Cuando alguien se refiere al honor de una persona, generalmente, hace alusión al reconocimiento o estimación social del que ésta goza. La sociedad impone determinadas normas o exigencias sociales a sus miembros, y a través de la valoración social e individual enjuicia permanentemente la conducta de los sujetos, premiándolos con la aceptación o sancionándolos con el rechazo.

El Diccionario filosófico de M. Rosental y P. Iudin define el honor como "Categoría moral; que expresa el reconocimiento, por parte de la sociedad, de todo cuanto merece una alta estimación en la manera de actuar de un individuo, de una colectividad, de una institución"; ${ }^{43}$ y luego, asumiendo a juicio de este autor una posición reduccionista, identifica al linaje como causa del honor en el feudalismo, a la posesión de riquezas como causa del honor en el capitalismo, y a los méritos ante el pueblo como causa de honor en el socialismo; si este planteamiento tiene algo de veraz, no es toda la verdad, pues la absolutización es negativa para cualquier pretensión científica.

43 Rosental, M. e Iudin, P., Diccionario filosófico, La Habana, Editora Política, 1981, p. 223 . 
El honor también es definido como una cualidad moral vinculada al cumplimiento del deber, la virtud, el mérito y el heroísmo. Se manifiesta en el ámbito familiar, laboral y social a través de la fama, la gloria o simplemente mediante la buena opinión de la que se disfruta. Generalmente el honor es visto como un factor para obtener de la sociedad favores materiales o espirituales, como buenos empleos, riqueza personal o estatus social.

Para muchos autores, la dignidad humana es vista como la suma de caracteres o cualidades que configuran ante nosotros la existencia de un determinado ser y no otro, como identidad de dicho ser entre los hombres; como un conjunto de rasgos que sumados unos a otros confirmarían la pertenencia de un ser dado a la especie humana. Por lo tanto, la dignidad humana se encuentra en el fundamento del derecho al honor.

Para el constitucionalista Eduardo Espín: "El honor, en tanto que aprecio y estima que una persona recibe en la sociedad en la que vive, es un derecho fundamental que afecta íntimamente la dignidad de la persona". ${ }^{44}$ Obsérvese que en esta definición sobresalen los términos aprecio y estima, entendidos como consideración que tiene la sociedad de una persona en un sentido objetivo, a la vez que manifiesta una vinculación de estas categorías con la dignidad de la persona.

De lo expresado se desprende que el derecho al honor sería como una derivación, como emanación de la dignidad humana, entendido por ello como derecho a ser respetado por las demás personas. Sin embargo, el derecho al honor tiene un carácter autónomo e independiente de otros similares como el derecho a la intimidad y a la propia imagen, aunque erradamente se les confiera el mismo tratamiento jurídico por los autores y las normas del derecho positivo.

Autores especializados en las ciencias penale ${ }^{45}$ han logrado identificar la diferencia sustancial entre la intimidad y el honor por vía de la determinación del bien jurídico que se protege en cada caso. El bien jurídico intimidad lo definen como libertad potenciada en el ámbito de lo íntimo, constituida por las costumbres, hábitos y modos privados de asumir la convivencia humana, en lo personal y familiar, en su índole cultural y espiritual, es la libertad personal de asumir la vida fuera de las obligaciones sociales; mientras que

44 López Guerra, Luis et al., Derecho constitucional, vol. I. El ordenamiento constitucional. Derechos y deberes de los ciudadanos, Valencia, Tirant lo Blanch, 2000, p. 146.

45 Edmundo Larramendi Domínguez, Elia Esther Rega Ferrán, Mayda Goite Pierre, Óscar Luis Moret Hernández, Carlos Alberto Mejías Rodríguez y Arnel Medina Cuenca. 
el bien jurídico conformado por el derecho al honor lo definen como el patrimonio moral que le corresponde a cada persona.

Otros autores enfatizan en la relación cuasi conflictual que se puede establecer entre los derechos al honor y la dignidad, y el derecho a la libertad de expresión. Al respecto, plantean Blas Guerrero y García Cotarelo:

El derecho al honor, la intimidad personal y familiar y la propia imagen constituyen un claro límite a la libertad de expresión [...] Se estima en todo caso que esa protección no cubrirá los hechos de dominio público, aquellas circunstancias personales que el interesado, a través de su comportamiento, no consideradas de naturaleza reservada o cuando los hechos objeto de información [...] afectan exclusivamente a actividades que tengan relación directa con las causas de proyección pública de la persona afectada. ${ }^{46}$

La dignidad humana y el honor son contenidos de las relaciones sociales que han estado presentes desde el origen de la humanidad. Ambas categorías tienen una fuerte trascendencia tanto para la moral como para el derecho; desde sus primeras manifestaciones se trataba de normas morales que llegaron a tener efecto jurídico. Esto se valida porque el honor se refiere a un modo de conducta, que de corresponderse con las exigencias sociales, se retribuye mediante la adquisición de determinados derechos, siendo el más común el derecho al buen nombre.

Reflexionando sobre la naturaleza jurídica del concepto honor se puede apreciar tres posiciones teóricas: la que se concibe desde un punto de vista subjetivo, refiriéndose a la autoestima producto de la autovaloración que tiene una persona sobre sí misma; la objetiva, que refiere a la consideración que tiene la sociedad sobre una persona, a partir de valorar su conducta, o el cumplimiento de las normas establecidas a nivel social.

Los autores se refieren a una posición teórico doctrinal intermedia, la cual consideran más contemporánea y por ello aceptada; esta "concibe el honor desde un punto de vista cultural, como el resultado del juicio de los miembros de la comunidad sobre el comportamiento de una persona con relación a sus deberes o como derecho coincidente con la dignidad propia de

46 Blas Guerrero, Andrés y García Cotarelo, Ramón, Teoría del Estado y sistemas políticos, t. I: Parte general, teoría del Estado, 1986, p. 209. 
la condición humana, en virtud de la cual todos los seres humanos gozan de la facultad de ser respetados por los demás". ${ }^{47}$

El honor suele vincular a las personas con elementos que conforman la estructura de la sociedad, o por lo menos con ramas de la actividad humana y con los oficios y profesiones. En este sentido se reconoce la existencia del honor profesional, comercial, científico u otros.

Otra arista interesante es analizar qué tratamiento han dado las diferentes ramas o materias del derecho al honor. Se percibe en este sentido una expresión trilateral o tridimensional del referido derecho: en la materia constitucional se concibe como derecho fundamental; en el derecho civil como derecho subjetivo de la personalidad, y en derecho penal como bien jurídico.

La complejidad para designar al repertorio de derechos dentro del que se considera el derecho al honor es tal, que incluso, en el derecho constitucional y en los tratados internacionales aparecen otras designaciones como derechos humanos, libertades individuales y derechos del hombre.

El constitucionalista español Pérez Tremps ${ }^{48}$ atribuye esta diversidad de designaciones en el derecho constitucional a varios motivos, que van desde la perspectiva metodológica con que se analiza una misma realidad jurídica, pasando por la dimensión histórica, hasta llegar a la estructura interna de los distintos derechos.

A pesar de esta diversidad de designaciones, el autor coincide con Pérez Tremps cuando plantea "desde el punto de vista constitucional, el concepto de 'derechos fundamentales' resulta el más adecuado; ello porque, por otra parte, la expresión 'derechos fundamentales' sirve para poner de manifiesto la naturaleza especial que dichos derechos poseen: su consideración como elemento básico y preeminente del ordenamiento, frente a la naturaleza 'ordinaria' que los demás derechos subjetivos poseen". ${ }^{49}$

También debe considerarse que la doctrina y la legislación constitucional emplean el término derechos fundamentales en dos sentidos: uno amplio, y considerado técnicamente incorrecto por algunos autores, ${ }^{50}$ que le atribuye tal calificativo a cualquier derecho plasmado en la Constitución; y uno estricto, reservado para aquellos derechos que conforman el núcleo

47

48 Varios autores, op. cit., p. 171.

48 López Guerra, Luis et al., op. cit.

49 Ibidem, p. 138.

50 Pablo Pérez Tremps, Luis López Guerra, Eduardo Espín, Joaquín García Morillo, Miguel Satrústegui, etcétera. 
central del estatus jurídico del individuo. Estos derechos son los que en constituciones como la española manifiestan una especial rigidez exigida para su reforma, y gozan de un reforzado sistema de garantías normativas en las leyes de desarrollo.

Autores, como el español Pérez Luño, definen los derechos fundamentales como "el conjunto de facultades, instituciones y prerrogativas que en cada momento histórico concretan la exigencia de la dignidad, la libertad y la igualdad humanas, las cuales deben ser reconocidas positivamente por los ordenamientos jurídicos". ${ }^{51}$

Para Villabella Armengol ${ }^{52}$ los derechos fundamentales son aquellos, dentro de los mismos derechos constitucionales y humanos, que además de positivarse han logrado que se les instrumenten vías garantistas seguras para su defensa e implementación.

Por su parte, el derecho civil concibe los derechos subjetivos de la personalidad "como el poder jurídico o el conjunto de facultades conformadoras de una unidad que un ordenamiento jurídico otorga a una persona, a la que por ello se le permite un determinado comportamiento o se le concede la oportunidad de exigir de otra una prestación o una conducta debida, siempre para la consecución de ciertos fines lícitos". ${ }^{33}$

El bien jurídico es para el derecho penal una relación social dinámica, que expresa la posición de los sujetos intervinientes en dicha relación, sus formas de vincularse entre sí y con los objetos de la realidad, en el trascurso del desarrollo histórico y en un contexto determinado.

La expresión trilateral del derecho al honor en un ordenamiento jurídico puede crear relaciones contradictorias, como la declaración en materia constitucional del carácter irrenunciable de los derechos fundamentales, y la posibilidad en sede penal de renunciar a iniciar un proceso por la vulneración del referido derecho por parte de su titular, en virtud de que dichos delitos son perseguibles a instancia de la parte afectada. Estas contradicciones pueden evidenciar situaciones de falta de unidad regulatoria, de integridad y de sistematicidad en un ordenamiento jurídico determinado.

51 Peréz Luño, A. Enrique, Los derechos fundamentales, Madrid, Tecnos, 1994, p. 44.

52 Villabella Armengol, Carlos, "Los derechos humanos. Consideraciones teóricas de su legitimación en la Constitución cubana”, en Prieto Valdés, Martha, op. cit., p. 91.

53 Valdés Díaz, Caridad del Carmen, Derecho civil. Parte general, La Habana, Félix Varela, 2005, p. 134. 
Se coincide con la profesora Caridad Valdés Díaz cuanto expresa: "los conceptos de honor, dignidad o fama no son inmutables [...] su contenido no es el mismo en todas las épocas; cada formación económico social imprime determinadas exigencias o patrones. Son categorías de marcado carácter social, de modo que varían con frecuencia". ${ }^{54}$

Como se ha explicado, en el campo jurídico se emplean idénticamente, o al menos en sentido semejante, los términos derechos constitucionales, derechos humanos y derechos fundamentales. Sin embargo, el autor considera más correcto el empleo del término derechos fundamentales, en lo relativo a su objeto de investigación.

Además del ya referido planteamiento de Pérez Tremps, sobre la naturaleza especial de los llamados derechos fundamentales, su carácter de básicos y preeminentes dentro del ordenamiento jurídico, frente a otros derechos subjetivos; el autor asume que no todos los derechos plasmados en la Constitución tienen el carácter de fundamentales; del mismo modo, el término derechos humanos se ha empleado preferentemente para la doctrina y los tratados de derecho internacional.

Desde esta perspectiva teórica resulta significativo retomar críticamente, con enfoque dialéctico, como se ha dicho, algunos planteamientos de la teoría de los derechos fundamentales de Robert Alexy. ${ }^{55}$

La principal limitación que se percibe en la teoría de los derechos fundamentales de Alexy es que ésta tiene su origen en la valoración crítica de una disposición normativa y su jurisprudencia, y no en la valoración crítica de las teorías existentes hasta ese momento.

La Ley Fundamental alemana, y la jurisprudencia del Tribunal Constitucional Federal alemán, parecen ser casi la única fuente de sustentación de la teoría del profesor de Kiel, sólo matizada con algunos planteamientos teóricos derivados igualmente de ese contexto alemán. De esa manera se llega a generalizaciones demasiado amplias, partiendo de un contexto jurídico muy limitado, aunque rico en la legislación y la práctica constitucional. Esto provoca la imposibilidad de extrapolar algunas soluciones a otros contextos, que no gozan del mismo desarrollo legislativo, jurisprudencial y teórico.

54 Ibidem, p. 145.

55 Teoría fundamentada por el jurista alemán Robert Alexy, desarrollada en su libro Teoría de los derechos fundamentales, publicado en 1984 y con versión al español de 1994. Esta teoría recibe la influencia del normativismo de Kelsen y del naturalismo jurídico de Radbruch, pero en ella se intenta superar algunas de las limitaciones de ambas escuelas. 
Se coincide con el jurista alemán en considerar la existencia de tres dimensiones en el campo de los derechos fundamentales; al respecto Alexy plantea:

Las razones por las cuales ello es así son fáciles de comprender. Para poder dar una respuesta a qué es lo jurídicamente debido, hay que conocer el derecho positivamente válido. El conocimiento del derecho positivamente válido es tarea de la dimensión empírica. El material dotado de autoridad objetable en la dimensión empírica no basta, en todos los casos más o menos problemáticos, para fundamentar vinculantemente el juicio jurídico concreto de deber ser. Ello hace necesario recurrir a valoraciones adicionales y, así, a la dimensión normativa. Presupuesto de la racionalidad de toda ciencia es la claridad conceptual, la no contradicción y la coherencia. Los numerosos problemas sistemático-conceptuales de los derechos fundamentales muestran cuán importante es el papel de la dimensión analítica dentro del marco de una ciencia práctica de los derechos fundamentales que desee asumir su tarea de una manera racional. ${ }^{56}$

De esta manera, Alexy propone tres dimensiones del derecho que difieren aparentemente de las propuestas por la concepción trialista de Werner Goldschmidt: mientras el primero plantea la existencia de una dimensión empírica, otra normativa y una tercera analítica para los derechos fundamentales; el segundo fundamenta una dimensión normativa, otra fáctico social y una tercera axiológica, cuando de la totalidad del mundo jurídico se trata.

El autor de este trabajo no considera irreconciliables las propuestas, pues expresan para él dos plataformas de proyección del derecho diferentes: una hacia "dentro", a lo puramente técnico-jurídico, y otra hacia "fuera", hacia lo jurídico social; pero ambos enfoques de la proyección jurídica tienen en común lo normativo como elemento de conexión, como área tangencial, que particulariza el campo del derecho como singularidad dentro del saber social, de las llamadas ciencias sociales. Esas proyecciones sólo tendrían un fin metodológico, para un estudio profundo del derecho, pues en la realidad jurídica nunca podrían separarse.

Otra idea de la teoría de los derechos fundamentales que este autor considera válida, a los efectos de su objeto de investigación, es la composición

56 Alexy, Robert, Teoría de los derechos fundamentales, Madrid, Centro de Estudios Constitucionales, 1993, p. 34. 
que propone Robert Alexy para las normas de derecho fundamental. Éste plantea que dichas normas se encuentran formadas por reglas y principios.

Sobre el carácter de las reglas y principios como elementos estructuradores de las referidas normas expone:

Tanto las reglas como los principios son normas porque ambos dicen lo que debe ser. Ambos pueden ser formulados con la ayuda de las expresiones deónticas básicas del mandato, la permisión y la prohibición. Los principios, al igual que las reglas, son razones para juicios concretos de deber ser, aun cuando sean razones de un tipo muy diferente. La distinción entre reglas y principios es pues una distinción entre dos tipos de normas. ${ }^{57}$

Pero, ¿qué valor real tiene para el derecho al honor la distinción entre reglas y principios como tipos diferentes de normas de derecho fundamental? La respuesta a esta interrogante parte de la propia argumentación de Alexy.

Dicho autor defiende la idea de diferenciar las reglas y los principios como tipos distintos de normas de derecho fundamental; en primer lugar por los grados diferentes de generalidad que expresan, atribuyendo a las reglas comportamientos debidos específicos (se cumplen o no), mientras que a los principios le atribuye grados de cumplimiento más generales (se cumplen en diferentes niveles). Esto es lo que él llama "mandatos de optimización". ${ }^{58}$

También significa una diferencia cualitativa entre reglas y principios. En cuanto a la falta de coherencia en los ordenamientos jurídicos en el caso de los últimos se aprecia la llamada colisión de principios, mientras que para las primeras se constata un conflicto de reglas. El método o procedimiento de solución en ambos casos es bien diferente.

Para Alexy, algo en lo que coincide al autor, el conflicto de reglas sólo puede ser solucionado introduciendo una cláusula de excepción que elimina el conflicto, o declarando no válida una de las reglas..$^{59}$ Estas son las únicas formas mediante las cuales se puede eliminar unos juicios de deber ser contradictorios, que expresan consecuencias jurídicas diferentes, confrontadas entre sí, para un mismo supuesto jurídico, ya sea de hecho o de derecho.

Para los principios, el profesor de Kiel propone otro método de solución, el cual expone de la siguiente manera:

58

58 Ibidem, pp. 86 y 87.

59 Ibidem, p. 88. 


\begin{abstract}
Cuando dos principios entran en colisión — tal como es el caso cuando según un principio algo está prohibido y, según otro principio, está permitidouno de los dos principios tiene que ceder ante el otro. Pero, esto no significa declarar inválido al principio desplazado ni que en el principio desplazado haya que introducir una clausula de excepción. Más bien lo que sucede es que bajo ciertas circunstancias uno de los principios precede al otro. Bajo otras circunstancias, la cuestión de la precedencia puede ser solucionada de manera inversa. Esto es lo que se quiere decir cuando se afirma que en los casos concretos los principios tienen diferente peso y que prima el principio con mayor peso. ${ }^{60}$
\end{abstract}

Esto le permite afirmar que los conflictos de reglas se llevan a cabo y se solucionan mediante la determinación de la validez; mientras que la colisión de principios se resuelve en la dimensión del peso, es decir, determinando el de mayor peso para el caso concreto, siendo éste el que debe prevalecer para dicha situación particular.

La solución en la colisión de principios viene dada por lo que Robert Alexy llama ponderación de bienes, sustentada en la "Ley de colisión". ${ }^{61}$ La colisión de principios se expresa como una relación de tensión entre intereses opuestos, y su solución consiste en ponderar cuál de los intereses, abstractamente del mismo rango, posee mayor peso en el caso concreto.

La denominada "Ley" supone el establecimiento de una relación de precedencia condicionada entre los principios en colisión. Como propone Alexy: "La determinación de la relación de precedencia condicionada consiste en que, tomando en cuenta el caso, se indican las condiciones bajo las cuales un principio precede al otro. Bajo otras condiciones, la cuestión de la precedencia puede ser solucionada inversamente". ${ }^{62}$

El planteamiento en sí es complejo para el caso de la colisión del derecho al honor con la libertad de expresión. Si se entendiera el derecho fundamental al honor como norma principio, una de las posibilidades que da el profesor de Kiel para los derechos fundamentales, se estaría en una situación excepcional de precedencia incondicionada, siempre que el honor se conciba en el ámbito de la dignidad humana.

Alexy plantea que para todos los supuestos de determinación de la relación de precedencia deben establecerse las condiciones que determinan la regla

\footnotetext{
60 Ibidem, p. 88.

61 Ibidem, p. 90.

62 Ibidem, p. 92.
} 
de ponderación, lo que permite hallar la norma principio que debe prevalecer para ese caso concreto; sin embargo advierte que la única excepción a la aplicación de la regla de ponderación es cuando uno de los principios en colisión es la dignidad humana. Esto provocaría una precedencia absoluta o incondicionada que haría prevalecer siempre cualquier derecho asociado a la dignidad humana, si es uno de los que entra en colisión.

De lo planteado se puede concluir que en una colisión o conflicto de normas, en que una de las normas proteja el derecho al honor, se podrían dar tres soluciones teóricas diferentes: primero, que el derecho fundamental al honor sea considerado una norma regla de derecho fundamental, y que por lo tanto lo que pueda apreciarse sea un conflicto de reglas, que se soluciona introduciendo una cláusula de excepción, que elimina el conflicto, o declarando no válida una de las reglas.

El segundo supuesto es un conflicto o colisión de normas de derecho fundamental en que una de las normas sea de derecho al honor, y que el derecho fundamental al honor se considere una norma principio de derecho fundamental con identidad propia, no asociada a la dignidad humana. En este caso la solución sería establecer una relación de precedencia condicionada, mediante una ponderación de derechos en conflicto, para determinar qué derecho debe prevalecer en el caso concreto. Aquí son importantes las condiciones en que se desarrolla el conflicto, para la aplicación de la "Ley de ponderación".

El tercer supuesto es un conflicto o colisión de normas de derecho fundamental en que una de las normas protege el derecho al honor, y que el derecho fundamental al honor se considere una norma principio de derecho fundamental dependiente o asociada a la dignidad humana. En este caso, el principio de la dignidad humana es considerado una excepción, por lo que no se sujeta a la regla de la relación de precedencia condicionada, sino a la de precedencia incondicionada.$^{63}$ En este caso particular, siempre el principio que debe prevalecer es el asociado a la dignidad humana. Aquí las condiciones en que se desarrolla el conflicto no son importantes, pues el principio que debe prevalecer está predeterminado.

Una apreciación integral de la regulación y protección efectiva del derecho al honor supone una visión transversal de este derecho para todo el ordenamiento jurídico, partiendo de la Constitución e irradiando a las demás ramas del derecho. Esta visión propone que el derecho fundamental

63 Ibidem, p. 92. 
al honor pueda gozar de un desarrollo tal que se exprese en las diferentes ramas del derecho como norma regla, como norma principio relativamente independiente y como norma principio asociada a la dignidad humana.

El autor propone una variedad de soluciones teóricas y empíricas para el conflicto entre el derecho fundamental al honor y el derecho a la libertad de expresión, según la función ${ }^{64}$ que cumpla dicho derecho y la rama en que esté presente; aplicando en cada uno de los casos las regla de solución de conflicto o colisión que más se ajuste al caso concreto.

Partiendo de los postulados teóricos enunciados se impone la fundamentación de la crítica propositiva para la regulación del derecho al honor en el caso cubano.

La propuesta de regulación del derecho al honor en el ordenamiento jurídico cubano se sustenta en tres ideas que a juicio del autor deben ser rectoras, por lo que pueden identificarse como principios regulatorios y funcionales de dicho ordenamiento. Estas ideas o principios son: el de unidad regulatoria, el de sistematicidad regulatoria y el de integridad funcional. Al ser propuestos como principios tienen la impronta de la subjetividad humana, por lo tanto no gozan de existencia objetiva propia, sino que deben ser implementados por el hombre de manera consciente, con la finalidad de que el derecho al honor sea garantizado con eficacia.

La unidad regulatoria supone tanto la unidad interna como la unidad externa, en materia de regulación del derecho al honor. Cuando se hace alusión a la unidad interna en el ordenamiento jurídico, el autor se refiere a la "coherencia esencial de sus dictados de conducta y sus normas de adjudicación, reconocimiento y de cambio y, sobre todo, por la coherencia y homogeneidad de las normas de conducta que se establecen y cómo se establecen [...] la unidad interna viene dada por la unidad de intención política, social, económica y ética". ${ }^{65}$

La unidad interna en la regulación del derecho al honor supone entonces que en un ordenamiento jurídico todas las normas sobre esta materia, sean primarias o secundarias, sustantivas o adjetivas, tengan el rango que tengan, y sean de la rama constitucional, administrativa, penal, del derecho civil y de familia, procesal, o de cualquier otra, deben tener las mismas intenciones

64 Como norma regla; como norma principio no asociada a la dignidad humana, o como norma principio asociada a la dignidad humana.

65 Fernández Bulté, Julio, Teoría del Estado y del derecho. Teoría del derecho, La Habana, Félix Varela, 2005, t. II, p. 155. 
políticas, proteger semejantes intereses económicos y sociales; y deben ser concordantes con sus postulados ideológicos y éticos, principalmente sobre la materia regulada.

En cuanto a la unidad regulatoria externa, el autor se refiere a la necesaria armonía y orden que debe existir en la jerarquización del aparato legal. Esto supone la implementación efectiva de la jerarquía normativa y la supremacía constitucional como principios generales del derecho. La efectiva aplicación de estos principios se materializaría si las normas inferiores se atienen a las superiores, y todas al dictado de la Constitución.

No se concibe entonces que en materia penal se establezcan sanciones para los delitos contra el honor, como bien jurídico a proteger, y que en la Constitución de la República, ley de jerarquía suprema, y de la cual emana el reconocimiento y la protección estatal a los derechos fundamentales, el honor no sea reconocido y su protección garantizada. Esta incoherencia se hace extensiva a cualquier rama del ordenamiento jurídico, permitiendo en el caso cubano, por ejemplo, que la promoción de una demanda para proteger el honor en sede civil, contra una vulneración de los derechos inherentes a la personalidad, al amparo del artículo 38 del Código que regula la materia, no pueda efectuarse, por faltar el asidero constitucional que exige el mismo texto. Se verifica en este caso la falta de unidad regulatoria antes señalada.

La segunda idea o principio es el de la sistematicidad regulatoria, la cual expresa la necesidad de una articulación estructural y funcional en el ordenamiento jurídico en cuanto a la regulación del derecho al honor. Esto supone que a cada norma sustantiva, en lo relativo al referido derecho, le corresponda la norma adjetiva más idónea; que el derecho quede consagrado de manera clara, con identidad propia, y preceptiva desarrolladora, en todas las ramas del derecho en que deba estar; que las instituciones jurídicas implicadas se correlacionen adecuadamente; que no se manifieste en las diferentes ramas $\mathrm{y}$, dentro de una misma, antinomias y desajustes funcionales.

Aunque asumido por Fernández Bulté como expresión de unidad externa, este autor acoge como requisito del principio de sistematicidad regulatoria, lo planteado por dicho autor cuando dijo que era necesario "que a su vez las normas de diferentes ramas del derecho presenten también armonía funcional y no tengan contradicciones en su contenido o en las dinámicas funcionales que establecen". ${ }^{66}$ 
En cuanto a la integridad funcional hace alusión a que todo lo estipulado en el ordenamiento jurídico en materia de derecho al honor debe cumplimentarse, debe ser cumplido con diligencia por las autoridades y funcionarios implicados, según señala la ley. Esto va expresado en el sentido de que no puede ser letra muerta, no puede alegarse falta de recursos o de prioridad para propiciar una inejecución de la ley en esta materia. Dicho principio supone que lo estipulado en las normas sobre el tema será observado por las autoridades competentes, sus agentes y funcionarios, con la misma celeridad con que se busca dar protección al derecho de propiedad, o a la integridad física y a la vida de las personas.

Con base en la aplicación de esos principios o ideas rectoras, el autor propone que se incorpore a la Constitución de la República de Cuba, en su capítulo VII sobre Derechos, deberes y garantías fundamentales, un artículo que quede redactado de la siguiente manera: el Estado reconoce y garantiza el derecho de todo hombre a su dignidad humana y al honor personal. La ley regulará las formas y procedimientos para hacer efectivos estos derechos. Más adelante debe añadirse: ninguno de los demás derechos reconocidos en esta Constitución, o en sus leyes de desarrollo, podrá ser esgrimido para vulnerar la dignidad humana y el honor de las personas. No se considerará una vulneración al honor la imputación de hechos ciertos, siempre que se utilicen sin la intención de denigrar a la persona ofendida.

Es criterio del autor que en otro párrafo del mismo artículo debe adicionarse: el derecho al honor es extensivo a las instituciones estatales y no estatales, a las empresas y a sujetos colectivos de la sociedad civil. En este caso estarán legitimados para pedir protección cualquier persona natural o jurídica que se sienta razonablemente afectada por una agresión al honor.

Este planteamiento, doctrinalmente polémico, sobre hacer extensivo el reconocimiento del derecho al honor a las personas jurídicas, se sustenta en la doctrina del honor objetivo. En este sentido se coincide con el profesor de la Facultad de Derecho de la Universidad de Castilla-La Mancha, Tomás Vidal Marín, cuando plantea:

A partir de aquí es posible afirmar que las personas jurídicas deberán ser titulares de aquellos derechos fundamentales que sean acordes con la finalidad que persiguen, esto es, las personas jurídicas deberán ser titulares de aquellos derechos fundamentales encaminados a la protección del objeto o finalidad perseguida por la misma (un ejemplo sencillo, un sindicato deberá ser titular de la libertad sindical). Pero además, las personas jurídicas deberán 
ser titulares de aquellos derechos fundamentales que aparezcan como medio o instrumento necesario para la consecución de la referida finalidad. Es, precisamente, en este ámbito en el que entra en juego el derecho fundamental al honor, y ello porque el desmerecimiento en la consideración ajena sufrida por determinada persona jurídica conllevará, sin duda, la imposibilidad de que ésta pueda desarrollar libremente sus actividades encaminadas a la consecución de sus fines. ${ }^{67}$

En materia penal, y para que se realicen la unidad regulatoria, la sistematicidad y la integridad, se propone reformar la redacción del artículo 321.1, del título XII Delitos contra el honor, del Código Penal vigente. En vez de decir "Los delitos de calumnia e injuria sólo son perseguibles en virtud de querella de la parte ofendida", ${ }^{68}$ lo cual supone la posibilidad de renuncia del derecho al honor, algo que contradice el carácter irrenunciable de los derechos fundamentales, y por tanto de la norma constitucional; y en su lugar se plantea que quede redactado de la siguiente manera: los delitos contra el honor requieren de la denuncia de la parte ofendida.

Aunque la redacción enunciada no resuelve definitivamente la posibilidad de renunciar al derecho, algo inconcebible en materia de derechos fundamentales, lo atenúa, al hacer de estos delitos una variante de lo que en la doctrina se ha dado en llamar semipúblicos, porque una vez efectuada la denuncia, se estipula la intervención del Ministerio Público en representación del Estado y protegiendo los intereses de la parte ofendida.

Otra modificación necesaria al Código Penal es la incorporación de una sanción accesoria a estos tipos de delitos que persiguen proteger a un bien jurídico tan sensible como el patrimonio moral de las personas. En este sentido se propone un tercer apartado del artículo 321 que disponga: en todos los casos que sea probada la culpabilidad de un acusado de delitos contra el honor, el Tribunal deberá imponer como sanción accesoria la retractación moral del ofensor, en un ámbito similar a aquél donde produjo la ofensa, y utilizando iguales medios.

También resulta interesante valorar la posibilidad de reformular el contenido regulador del artículo 319 de la Ley penal cubana, en el sentido de hacer de la calumnia, como en la mayoría de las leyes penales del mundo,

67 Vidal Marín, Tomás, "Derecho al honor, persona jurídica y tribunal constitucional”, Revista para el Análisis del Derecho, Barcelona, núm. 1, enero de 2007, p. 8.

68 Ley número 62/87, op. cit., p. 135. 
una figura agravada del delito de injuria; y que ésta base sus elementos constitutivos en la imputación de un falso delito. Igualmente debe revisarse la definición del delito de difamación, el cual no tiene paralelo en la mayoría de los códigos penales del mundo, encontrándose éste subsumido dentro de la calumnia, o en alguna de las disposiciones relativas a los delitos contra la jurisdicción y la administración.

El autor no es ajeno al reclamo de muchos constitucionalistas en el sentido de despenalizar los delitos contra el honor y transferir esta materia a la legislación civil. Esto sólo podría realizarse cuando se cuente con una sólida Ley de protección civil al honor, la que instituya claramente los procedimientos a tramitar en caso de violaciones. Se comparte esta posición, al parecer defendida por María Cristina Fix Fierro ${ }^{69}$ pero no se considera aplicable en las actuales condiciones de Cuba, a no ser que se haga acompañar por una profunda reforma al ordenamiento jurídico, lo cual debe estar respaldado por una fuerte voluntad política y de los órganos jurisdiccionales para su aplicación.

Se propone además que se instituya en materia procesal un proceso de naturaleza constitucional o civil que permita explícitamente demandar a una persona por violación del derecho al honor de las personas jurídicas naturales y morales. Esta norma procesal debe concebir, en caso de que haya derechos fundamentales en conflicto, donde uno de esos derechos sea el derecho al honor, varias reglas de solución basadas en la teoría de Robert Alexy.

Esta gama de soluciones debe incluir la excepción o derogación de Ley en caso de normas reglas de derecho fundamental en conflicto, en que uno de los derechos en conflicto sea el derecho al honor. La aplicación del método de ponderación en la solución de una colisión de normas principios de derecho fundamental, en que uno de los principios sea el derecho al honor y éste sea del tipo de los condicionados. Y una solución de precedencia absoluta a favor del derecho al honor, en caso de colisión de principios, en un supuesto de precedencia incondicionada, aplicable en los casos en que el derecho al honor sea concebido como parte de la dignidad humana.

Vale sugerir que pueda incluirse en la Constitución de la República, o en alguna de las normas de desarrollo los llamados derechos adjuntos de

69 Fix Fierro, María Cristina, "El derecho al honor como límite a la libertad de expresión”, disponible en http://www.juridicas.unam.mx.art.6. 
respuesta y rectificación, como derechos garantías para la protección y complementación efectiva del derecho al honor.

La articulación de estas propuestas, que se sustentan en la unidad regulatoria, la sistematicidad regulatoria y la integridad funcional, con base en los principios de supremacía constitucional y jerarquía normativa, permite articular el derecho al honor de forma plena y coherente, esto es que se realice sin lagunas ni antinomias de la Ley.

Las propuestas realizadas son apenas una parte de las profundas transformaciones que requiere el ordenamiento jurídico cubano, en el sentido de perfeccionarlo y modernizarlo; esto con el fin de sistematizarlo y otorgarle la unidad regulatoria que requiere en todas y cada una de las ramas del derecho. La presente investigación pretende ser un pequeño aporte a las aspiraciones de futuro que demanda la nación cubana.

\section{CONCLUSIONES}

El derecho al honor es una institución de carácter histórico y de significado variable, que ha estado asociada al derecho que todo ser humano tiene a su fama, dignidad, reconocimiento y respeto personal y social. En el campo del derecho constitucional se ha enfocado como derecho fundamental, en el civil como derecho subjetivo inherente a la personalidad, y en el penal como bien jurídico protegido bajo la rúbrica del patrimonio moral de las personas. En el último caso se ha enfocado como honor objetivo (estima y consideración que la sociedad tiene de uno) y como honor subjetivo (estima y consideración que uno tiene de sí mismo)

En varias Constituciones europeas y latinoamericanas, y en sus ordenamientos jurídicos, el derecho al honor, con diferentes designaciones, se reconoce y regula con gran amplitud, aunque esto no signifique siempre su realización material más plena.

En la tradición jurídica cubana el derecho al honor sólo ha tenido fuerte presencia en la rama del derecho penal, sobre todo desde el Código Penal español, extensivo a Cuba en 1879, perfeccionándose en el Código de Defensa Social de 1936, y ampliándose en los códigos penales de 1979 y 1987.

La protección del patrimonio moral y del honor de las personas en Cuba está parcialmente garantizada, a partir de que el Código Penal vigente lo establece, aunque en las disposiciones complementarias del título XII estipule que los delitos de calumnia e injuria sólo son perseguibles en virtud 
de querella, y que en la difamación se exija la denuncia de la parte ofendida; máxime cuando el derecho al honor no está reconocido como derecho fundamental, con identidad propia, en la Constitución de la República, y en el resto del ordenamiento jurídico no tiene la amplitud regulatoria que puede y debe tener.

La fundamentación de unas propuestas que se sustenten en la unidad regulatoria, la sistematicidad regulatoria y la integridad funcional, con base en los principios de supremacía constitucional y jerarquía normativa, permite articular el derecho al honor de forma plena y coherente, esto es que se realice sin lagunas ni antinomias de la Ley. 